\title{
Cost Containment and the Standard of Medical Care
}

\author{
E. Haavi Morreim $\dagger$
}

Rapid increases in health care costs have prompted business and government to impose cost containment measures that, in turn, pressure physicians to provide less care, particularly for the poor. Current malpractice law, however, requires the physician to provide ordinary and reasonable care, regardless of resources. Where resource constraints prevent the physician from delivering customary levels of care, a jurisprudential problem arises: if the law does not allow a physician to invoke cost constraints as a defense in a malpractice case, physicians may unfairly be held liable for inadequacies beyond their control; if the law does allow such a defense, adjusting the standard of care according to the available resources, poor patients may unfairly be denied legal remedies in malpractice actions.

In this Article, Professor Morreim explores this dilemma and finds the traditional rules and concepts of malpractice law inadequate to resolve it. Neither the methods for establishing standards of care (the locality rule, medical custom, and accepted practice) nor the legal principles of informed consent and equal protection can resolve the dilemma. Professor Morreim also considers several other proposed solutions: retaining the unitary standard of care; sharing liability with third parties; peer review with minimum standards; private contracting and exculpatory clauses; and resource-based reference groups. She concludes that these schemes are also inadequate, and recommends that the presumption of a unitary standard of care be rebuttable by appropriate evidence of economic constraints.

\section{INTRODUCTION}

The health care industry is in the midst of an economic revolution that will reshape not only medical resources but also the healing relationships that depend on thein. ${ }^{1}$ The basic story is probably familiar to the

$\dagger$ Assistant Professor, College of Medicine, University of Tennessee, Memphis. B.A. 1972, St. Olaf College; M.A. 1976, Ph.D. 1980, University of Virginia.

The author acknowledges with gratitude the helpful comments provided by Rand Rosenblatt, J.D.; Barry Furrow, J.D.; Robert Banks, J.D.; David Warren, J.D.; Nancy King, J.D.; William Applegate, M.D.; Terrence Ackerman, Ph.D.; Orley Lindgren, Ph.D.; Carson Strong, Ph.D.; and Walter Wadlington, LL.B. The anthor also thanks Carroll Dorgan, Lyndon Bittle, and the other editors of the California Law Review for their excellent editorial suggestions.

1. See Angell, Cost Containment and the Physician, 254 J. AM. MED. A. 1203 (1985); Boyle, Should We Learn to Say No?, 252 J. AM. MED. A. 782 (1984); Fuchs, The "Rationing" of Medical Care, 311 New ENG. J. MED. 1572 (1984); Levey \& Hesse, Bottom-Line Health Care?, 312 NEw ENG. J. Med. 644 (1985); Levinsky, The Doctor's Master, 311 New ENG. J. Med. 1573 (1984); 
reader. During the past two decades, the cost of health care in the United States has risen astronomically. Per capita health care costs have trebled since $1950,{ }^{2}$ rising fron $5 \%$ to nearly $11 \%$ of the GNP between 1960 and $1983 .^{3}$ By the end of 1987 , health care spending was predicted to reach over half a trillion dollars, anounting to $11.4 \%$ of the GNP.4 This escalation can be attributed partly to price inflation, the growing and aging of the population, the eniergence of costly new technologies, and the rapid growth of hospital facilities. ${ }^{5}$ Equally important, reimbursenient policies of third party payers have encouraged maximal use of those technologies and facilities. ${ }^{6}$ Retrospective paynient of a fee for each service performed has meant that the more services were performed for each patient, the more revenues would be received. Thus insulated from the economic costs of their decisions and inspired by the societal value that each patient should receive the best health care available, physicians and other providers have had powerful incentives to dehiver all nidicated care, and virtually no incentives to hold back. ${ }^{7}$

As a result, the federal Medicare program for the elderly now faces bankruptcy by the mid-1990's, ${ }^{8}$ while state Medicaid progranis for the poor are consuming excessive shares of limited state funds. ${ }^{9}$ Corpora-

McPhee, Myers, Lo \& Charles, Cost Containment Confronts Physicians, 100 ANNALS INTERNAL MED. 604 (1984) [hereinafter McPhee]; Morreim, The MD and the DRG, HASTINGS CENTER REP., June 1985, at 30; Nutter, Access to Care and the Evolution of Corporate, For-Profit Medicine, 311 NEW ENG. J. MED. 917 (1984); Relman, The New Medical-Industrial Complex, 303 NEW ENG. J. MED. 963 (1980); Thurow, Learning to Say "No," 311 NEW ENG. J. MED. 1569 (1984).

2. H. Aaron \& W. Schwartz, The Painful Prescription: Rationing Hospital Care 3 (1984).

3. Thurow, supra note 1, at 1569. For an excellent statistical examination of rising health care expenditures and their causes, see Wing, American Health Policy in the 1980's, 36 CASE W. RES. L. REV. 608 (1986).

4. Ginzberg, A Hard Look at Cost Containment, 316 NEw ENG. J. MED. 1151, 1151 (1987).

5. Angell, supra note 1, at 1207; Fuchs, supra note 1, at 1572; Levey \& Hesse, supra note 1, at 644; Relman, supra note 1, at 965; Thurow, supra note 1, at 1569-70; see also Schwartz, The Inevitable Failure of Current Cost-Containment Strategies, 257 J. AM. MED. A. 220 (1987); Wing, supra note 3 , at 646 .

6. Since the emergence of private insurance in the early 1930's, most labor contracts now routinely include hcalth care insurance as part of einployees' fringe benefits. In 1965, the government created Medicare and Medicaid programs to insure the nation's poor and elderly. See generally P. StaRR, The Social TRansformation OF AMERICAN MEdicine 290-378 (1982). While corporations now pay one-third of the nation's hcalth eare bill through employee insurance programs, state and federal governments pay more than $40 \%$. Goldsinith, The U.S. Health Care System in the Year 2000, 256 J. AM. MED. A. 3371, 3372 (1986).

7. See Thurow, supra note 1, at 1570; see also Aaron \& Schwartz, Hospital Cost Control: $A$ Bitter Pill to Swallow, HaRv. Bus. Rev., Mar.-Apr. 1985, at 160, 160-61 (1985) (describing development of health care "payment system designed to shield patients and providers from the cost of hospital care").

8. Board of Trustees Report, A Proposal for Financing Health Care of the Elderly, $256 \mathrm{~J}$. AM. MED. A. 3379, 3379 (1986). 1.

9. Cost Control Programs Proliferate, Surveys Show, Am. Med. News, Nov. 2, 1984, at 2, col. 
tions, which pay one-third of the nation's health care bill through employee fringe benefits, find it imcreasingly difficult to compete in the international marketplace as this significant part of their labor costs expands so rapidly. ${ }^{10}$

Over the last five years, government and corporate purchasers of health care have responded with major changes in the financing, and thereby in the dehivery, of health care. Prospective payments plans such as Medicare's Diagnostic-Related Groups (DRG) system now favor limiting, rather than expanding, hospitalization and the use of costly technologies. ${ }^{11}$ Numerous state Medicaid programs, as well as many commercial insurance companies, are either turning to prospective payment or requiring advance authorization of elective procedures with specified lengths of stay in the hospital. Many are limiting service or reimbursement levels, and all are more readily denying payment for questionable charges. Corporations are imposing on their employees a variety of utilization controls including preadmission review, mcreased employee copayinents and deductibles, and mandatory second opmions for specified procedures. Corporations also are encouraging competition between health care providers to create the most econoimical health care plans. New packages for dehivering care-such as health manitenance organizations (HMO's), preferred provider organizations (PPO's), independent practice associations (IPA's), and freestanding einergency and diagnostic centers-are proliferating rapidly. ${ }^{12}$

Though these financial rearrangements will affect virtually all health care consumers, they will especially affect the indigent for several reasons. First, governments are significantly less generous in their coverage of indigent citizens than private imdustry is with its einployees' health benefits, and some underprivileged citizens do not receive even this minimal assistance. Solne 35 million Americans-about $15 \%$ of the popula-

10. See Fine \& Sunshine, Malpractice Reform Through Consumer Choice and Consumer Education: Are New Concepts Marketable?, LAw \& Contemp. Prons., Spring 1986, at 213, 213-14; Thurow, supra note 1, at 1571; Wing, supra note 3, at 672-75.

11. Under DRG's, each patient's hospital admission is classified into one of 467 DiagnosticRelated Groups. The patient's diagnosis, together with selected factors such as his age, his gender, and whether a surgical procedure is performed, predetermines the reimburseinent which the hospital will receive for his care. Since the hospital can keep as profit any inoney not spent on that patient's care, it now has an incentive to discharge patients earlier and perform fewer interventions. See Vladeek, Medicare Hospital Payment by Diagnosis-Related Groups, 100 ANNALS INTERNAL MED. 576 (1984).

12. See Goldsmith, supra note 6, at 3372; Freiman, Cost Sharing Lessons from the Private Sector, HEALTH AFF., Winter 1984, at 85; Thurow, supra note 1; Slater, Bottom Line Medicine, Wall St. J., Apr. 24, 1987, at 80, col. 1; Scheier, States Eye DRG Pay for Medicaid, Am. Med. News, Sept. 6, 1985, at 2, col. 1, and 22, col.01; Study Cites Innovative State Actions to Control Hospital Cost, Am. Med. News, June 14, 1985, at 25, col. 1; Report: Employers Redesigning Health Benefit Plans to Cut Costs, Am. Med. News, Apr. 19, 1985 at 27, col. 1. 
tion-have no health care insurance whatever. ${ }^{13}$ Second, as governinent and private third party payers remove themselves from the reach of "cost-shifting"- hospitals' traditional means of caring for medically indigent patients by raising their charges to paying patients-there will be an even smaller pool of resources to care for the poor. ${ }^{14}$ Third, as private hospitals "skim" the most lucrative patients into their own operation and "duinp" nonpaying patients into public health care facilities, these latter agencies will have to stretch limited resources to care for the growing numbers of patients. ${ }^{15}$ Thus we face a situation, not so much of pervasive resource shortage, but of "stratified scarcity."

Consider, for exainple, The Regional Medical Center at Meinphis, a public hospital that provides over one-fourth of the indigent care for the entire state of Tennessee. Although "The Med's" uncoinpensated care costs were some $\$ 70$ million in 1986, witli the deficit soinetines accumulating as fast as $\$ 550,000$ per montli, the lospital received only $\$ 27$ inillion in operating expenses reimbursement from the county that mandates the care-a figure that has not clianged over the previous five years. ${ }^{16}$ Partly because of increased "dumping" by local private hospitals, The Med is soinetimes so crowded that some patients must be sent home earlier than might otherwise be optinial. ${ }^{17}$ Because the lospital cannot afford to purchase its own facilities for such procedures as cardiac catheterization, coronary bypass graft surgery, coronary angioplasty, magnetic resonance imaging or lithotripsy (ultrasonographic renal "stone-crushing"), patients must receive these services froin nearby facilities. For

13. Ansell \& Schiff, Patient Dumping, 257 J. AM. MED. A. 1500, 1501 (1987); Fuchs, The Counterrevolution in Health Care Financing, 316 NEw ENG. J. MED. 1154, 1155 (1987); Goldsmith, supra note 6 , at 3373 .

14. Goldsmith, supra note 6, at 3373; Cancila, Care of Indigents Called Critical Issue, Am. Med. News, Feb. 21, 1986, at 1, 30; Scheier, Burden of Indigent Care Shifted to States, Am. Med. News, Jan. 3, 1986, at 6; McIlrath, Uncompensated Care Needs More Attention, Am. Med. News, Oct. 4, 1985, at 32 .

15. Schiff, Ansell, Schlosser, Idris, Morrison \& Whitman, Transfers to a Public Hospital, 314 New Eng. J. Med. 552, 556 (1986); Schramm, Can We Solve the Hospital-Cost Problem in Our Democracy?, 311 NEw ENG. J. MED. 729, 730-32 (1984); Thurow, Medicine Versus Economics, 313 NEW ENG. J. MED. 611, 612-13 (1985); Waters \& Tierney, Hard Lessons Learned, 311 NEW ENG. J. MED. 1251, 1252 (1984); Wemiberg, McPherson \& Caper, Will Payment Based on Diagnosis-Related Groups Control Hospital Costs?, 311 NEw ENG. J. MED. 295, 299 (1984); Scheier, State Role in Caring for Needy is Seen Increasing, Am. Med. Ncws, Aug. 23, 1985, at 2, col. 1, and 16, col. 1.

16. Tompkins, "Solid Cash Inflow" Is Expected at Med, Com. Appeal (Memphis), May 29, 1987, at A1, col. 3 [heremafter Solid Cash Inflow]; Tompkins, Directors of Med Approve Budget, id., Apr. 25, 1987, at B10, col. 3; Williams \& Tompkins, Patients and the Med Hanging On Together at the End of the Rope, id., Nov. 12, 1986, at A1, col. 2; Tompkins, Health Care for Poor Reviewed, id., Nov. 7, 1986, at B12, col. 3.

17. Conversation with Dr. Arthur Kellerman, medical director of emergency room, The Regional Medical Center at Memphis (Oct. 21, 1986); see also Williams \& Tompkins, supra note 16, at A4, col. 1 . 
this, The Med inust pay "the going rate, minus five percent."18 Unless its financial situation improves significantly, The Med will be unable to continue purchasing these services for all patients who imight benefit. Further, as nonpaying patients fill beds that might otherwise have been occupied by paying patients, the hospital's capacity to shift costs is disappearing. And a steady accumulation of debt has necessitated the withdrawal of funds froin the institution's equity and capital bases. "We're a ship at sea, running out of coal, and starting to burn the furniture."19 If this situation continues, The Med will ultimately be unable to provide for its patients the same level of care they would receive were they paying patients at a private hospital. ${ }^{20}$

"Stratified scarcity" creates dileminas for physicians everywhere. Successful cost containment cannot occur without the systematic cooperation of physicians, who control soine 60 to $80 \%$ of health care spending through their decisions about which services and products to order for

18. Personal communication with Dr. James Brown, medical director, The Regional Medical Center at Memphis (Nov. 5, 1986).

19. Personal communication, Dr. James Brown, medical director, The Regional Medical Center at Memphis (Jan. 20, 1987); see also Williams \& Tompkins, supra note 16, at A4, col. 4. Two recent events have improved The Med's situation, at least temporarily. Early in 1987, its Medicaid patient per diem reimbursement rose from $\$ 774$ to $\$ 885$, thus averting the need for an emergency appropriation. Tompkins, Medicaid Bonus Puts Hospital on Sounder Financial Footing, Com. Appeal (Memphis), Jan. 31, 1987, at B7, col. 1. Also, a Medicaid certification office is being opened at the hospital, so that more eligible patients will be certified for financial assistance. Tompkins, Solid Cash Inflow, supra note 16. Also, according to Dr. Brown, some units of the hospital are providing surplus revenue. These units include the burn center, the trauma center, high-risk obstetrics, and neonatal intensive care.

20. Cook County Hospital in Chicago is imder similar constraints. This hospital provides $20 \%$ of the indigent care for the Chicago area. As private hospitals are less able to shift their costs of imdigent care to paying patients, the demands in this and other Chicago public hospitals have risen. These hospitals now operate with a deficit, and their patients must wait long periods of time, only to be seen by students and residents with minimal supervision. Aging, outdated buildings are expensive to replace, and new medical technology is difficult or impossible to afford. See Nutter, Medical Indigency and the Public Health Care Crisis, 316 NEW ENG. J. MED. 1156 (1987). The probleuns of Illinois and Tennessee are common to several states. For discussions of the ways in which California's recent Medi-Cal cutbacks have adversely affected access and quality of health care for the indigent, see Lurie, Ward, Shapiro \& Brook, Termination from Medi-Cal-Does It Affect Health?, 311 NEw ENG. J. MED. 480 (1984); Lurie, Ward, Shapiro, Gallego, Vaghaiwalla \& Brook, Termination of Medi-Cal Benefits, 314 NEw ENG. J. MED. 1266 (1986); Schneider \& Stern, Health Maintenance Organizations and the Poor: Problems and Prospects, 70 Nw. U.L. REv. 90, 126-38 (1975); Waitzkin, Two-Class Medicine Returns to the United States: Impact of the Medi-Cal Reform, LANCET, Nov. 17, 1984, at 1144. For a discussion of indigent care in the absence of a Medicaid program in Arizona, see Blendon, Aiken, Freeman, Kirkman-Liff \& Murphy, Uncompensated Care by Hospitals or Public Insurance for the Poor: Does it Make a Difference?, 314 NEw ENG. J. MED. 1160 (1986). For a discussion of the "dumping" problem in Texas, see Reed, Cawley \& Anderson, The Effect of a Public Hospital's Transfer Policy on Patient Care, 315 NEw ENG. J. MED. 1428 (1428). See generally Law, A Consumer Perspective on Medical Malpractice, LAw \& ConTEMP. ProBs., Spring 1986, at 305, 306-07; Wilensky, Solving Uncompensated Hospital Care: Targeting the Indigent and the Uninsured, HeALTH AFF., Winter 1984, at 50; Wrenn, No Insurance, No Admission, 312 NEW ENG. J. MED. 373 (1985). 
which patients. ${ }^{21}$ Therefore, for the first time, hospitals and health care payers are pressuring physicians to do less for their patients, to perform more procedures on an outpatient basis, and to discharge hospitalized patients earlier. ${ }^{22}$ Such pressures appear either through direct controls that himit the physician's options, such as requiring him to secure permission before ordering an expensive procedure, or through incentives that, though leaving the physician free to make his own decisions, impose consequences for financially (im)prudent behavior. "Carrots" of profit sharmg or bonuses may entice cost consciousness, while "sticks" such as letters of admonition or threatened loss of staff privileges may intimidate the physician. ${ }^{23}$

These pervasive economic changes are transforming the practice of medicine and challenging its ethics. ${ }^{24}$ They are also beginning to rewrite medical law. For example, the high cost of malpractice hitigation ${ }^{25}$ has fueled tort reform niovements across the country. ${ }^{26}$ Another vital jurisprudential question has received little attention, however. It concerns the standard of care that physicians owe their patients in an environment of limited health care resources. As health care resources become imcreasimgly strained, physicians may not always be able to provide customary levels of care, particularly for the poor. Should they nevertheless be held legally hable for the medical consequences of others' economic decisions? Or, as health care resources become imcreasingly stratified, should the standard of care become similarly stratified?

Currently, the law answers this question with an emphatic "no."

21. Spivey, The Relation Between Hospital Management and Medical Staff Under a Prospective-Payment System, 310 NEw ENG. J. MED. 984, 984 (1984); Capron \& Gray, Between You and Your Doctor, Wall St. J., Feb. 6, 1984, at 24, col 2.

22. Half of MDs Feel Pressure to Discharge Patients Early, Am. Med. News, Dec. 5, 1986, at 17, col. 1; McIlrath, MDs Say Hospitals Press for Early Patient Discharge, Am. Med. News, Dec. 13, 1985, at 1, col. 3 .

23. Egdahl \& Taft, Financial Incentives to Physicians, 315 NEW ENG. J. MED. 59 (1986); Hershey, Fourth-Party Adult Organizations: Practical and Legal Considerations, 14 LAW MED. \& Health CaRe 54, 61-62 (1986).

24. Brody, Cost Containment as Professional Challenge, 8 Theoretical MEd. 5 (1987); Kralewski, Dowd, Feldman \& Shapiro, The Physician Rebellion, 316 NEw ENG. J. MED. 339 (1987); Thurow, supra note 15; see also Fuchs, supra note 1; McPhee, supra note 1; Morreim, supra note 1; Thurow, supra note 1.

25. These costs induce many physicians to practice "defensive medicine," in which the physician undertakes medically unnecessary procedures in order to ward off potential malpractice risks. According to some estimates, defensive medicine may cost anywhere from $\$ 8.4$ billion to $\$ 13.7$ billion annually, depending on one's method of computation. Reynolds, Rizzo \& Gonzalez, The Cost of Medical Professional Liability, 257 J. AM. MED. A. 2776, 2778, 2781 (1987).

26. See generally Robinson, The Medical Malpractice Crisis of the 1970's: A Retrospective, LAw \& CONTEMP. Probs., Spring 1986, at 5. Currently, new increases in liability insurance costs arc prompting still further reforms. See AMERICAN MEdical Ass'N SPECIAL TASK Force on Professional Liability and Insurance, Professional. Liability 1N THE '80's, Report No. 2 (Nov. 1984); Rust, 23 States OK'd Reforms in '86, Am. Med. News, July 25, 1986, at 1, col. 1. For further discussion of these reforms, see infra text accoinpanying notes 94-101. 
With some adjustments for locality, malpractice law presumes that there is a unitary standard of care that a physician owes to each patient he undertakes to treat. ${ }^{27}$ That standard of due care requires the physician to "have and use the knowledge, skill and care ordinarily possessed and employed by members of the profession in good standing."28 Its specific content is found in the customary practices prevailing among reasonable and prudent physicians. ${ }^{29}$ This standard must not be compromised simply because the patient cannot afford to pay. The physician may, of course, refuse to accept a patient for any reason, mcluding the patient's indigence. ${ }^{30}$ But once the patient is accepted, "whether the patient be a pauper or a millionaire, whether he be treated gratuitously or for reward, the physician owes him precisely the same measure of duty, and the same degree of skill and care."31 The physician may not perform an madequate diagnostic work-up out of cost considerations, ${ }^{32}$ nor may she abandon the patient at a critical juncture because the patient cannot pay his fees. ${ }^{33}$ If her hospital lacks a CAT scanner, for example, she must refer patients needing the test to a facility that can provide it-even though

27. See Havighurst, Private Reform of Tort-Law Dogma: Market Opportunities and Legal Obstacles, LAw \& CONTEMP. PROBS., Spring 1986, at 143, 149; Hershey, supra note 23, at 61; King, In Search of a Standard of Care for the Medical Profession: The "Accepted Practice" Formula, 28 VAND. L. REV. 1213, 1234 (1975); Stone, Law's Influence on Medicine and Medical Ethies, 312 NEw ENG. J. MED. 309, 310 (1985); Note, Rethinking Medical Malpractice Law in Light of Medicare Cost-Cutting, 98 HaRv. L. REv. 1004, 1010 (1985).

28. W. Keeton, D. DobBs, R. Keeton \& D. OWen, Prosser and Keeton on Torts 187 (5th ed. 1984) [hereinafter Prosser \& KeETON]; see also Pike v. Honsinger, 155 N.Y. 201, 49 N.E. 760 (1898); Becker v. Janinski, 15 N.Y.S. 675, 676 (1891); A. HoldeR, Medical MALPRACTICE LAw 43-45 (2d ed. 1978); Marsh, Health Care Cost Containment and the Duty to Treat, $6 \mathrm{~J}$. LEGAL MED. 157, 160, 172 (1985); McCoid, The Care Required of Medical Practitioners, 12 VAND. L. REv. 549, 559 (1959).

29. Clark v. Uinited States, 402 F.2d 950, 952 (4th Cir. 1968); Kingston v. McGrath, 232 F.2d 495, 498 (9th Cir. 1956); King, supra note 27, at 1236; McCoid, supra note 28, at 605-14; Pearson, The Role of Custom in Medical Malpractice Cases, 51 IND. L.J. 528, 528 (1976); Robinson, Rethinking the Allocation of Medical Malpractice Risks Between Patients and Providers, LAW \& CONTEMP. Probs., Spring 1986, at 173; Note, supra note 27, at 1008; Note, An Evaluation of Changes in the Medical Standard of Care, 23 VAND. L. REv. 729, $741-42$ (1970).

30. Buttersworth v. Swint, 53 Ga. App. 602, 186 S.E. 770 (1936); Childers v. Frye, 201 N.C. 42, 158 S.E. 744 (N.C. 1931); Becker v. Janinski, 15 N.Y.S. 675 (1891); A. HoLDER, supra note 28, at 1-3, 372; Curran \& Moseley, The Malpractice Experience of Health Maintenance Organizations, 70 Nw. U.L. REV. 69, 78 (1975).

31. Becker, 15 N.Y.S. at 677 ; see also Tunkl v. Regents of Univ. of Calif., 60 Cal. 2d 92, 103, 383 P.2d 441, 44832 Cal. Rptr. 33, 40, (1963).

32. Marsh, supra note 28, at 170. See also Clark, 402 F.2d at 953; Kingston, 232 F.2d at 499; Sinith v. Yohe, 412 Pa. 94, 105, 194 A.2d 167, 173 (1963); Wilkinson v. Vesey, 110 R.I. 606, 615-16, 295 A.2d 676, 683 (1972); A. HoldER, supra note 28, at 77; Furrow, The Causes of "Wrongful Life" Suits: Ruminations on the Diffusion of Medical Technologies, 10 LAW MED. \& HEALTH CARE 11, 12 (1982).

33. Becker, 15 N.Y.S. at 677; Ricks v. Budge, 91 Utah 307, 314-16, 64 P.2d 208, 211-13 (1937); A. Holder, supra note 28 , at 126,373; W. WADLINGTON, J. WALTZ \& R. DWORKIN, CASES AND MATERIals on LAW AND MEdicine 470-73 (1980); Marsh, supra note 28, at 165, 178-85; Note, Professional Standards Review and the Limitation of Services, 54 B.U.L. REV. 931, 938-39 (1974). 
her hospital may have to pay with its own scarce dollars. ${ }^{34}$ Any form of nontreatment or madequate treatment that is based on nonmedical considerations such as cost could constitute a form of abandonment. ${ }^{35}$ This is not to say that physicians and hospitals must provide literally every therapeutic intervention that promises benefit, regardless of cost. The law has never required physicians to dehiver the highest possible standard of care ${ }^{36}$ Rather, it requires only that each patient receive at least "ordinary and reasonable" care. Heretofore, this requirement has not been difficult to satisfy. Prior to World War II, physicians had few interventions, costly or otherwise, to offer patients. As expensive technologies emerged, virtually unlimited third party reimbursement encouraged physicians to provide their patients with all services that promised potential benefit. Though not all citizens had access to the health care system, those who did were usually able to receive its full range of benefits. ${ }^{37}$

Recent upheavals in the financial structure of health care have begun to threaten this relative uniformity of care, prompting our jurisprudential inquiry into the standard of care. This Article argues that the law should not always hold physicians hable when "stratified scarcity" forces them to provide stratified levels of care. ${ }^{38}$ We must begin by understanding the dilemma that confronts physicians. Part I shows how physicians are now systematically wedged between their traditional fiduciary commitment to serve exclusively the interests of their patients, and their new-found role as key agents of resource allocation. Part II examines traditional legal concepts that might resolve the dilemma. These include the inethods by which the courts identify standards of medical care- (1) the locality rule, (2) medical custom, and (3) accepted practice, together with the "respectable minority"-and the principles of (4) informed consent and (5) equal protection. None of these concepts can adequately reconcile physicians' long-standing fiduciary obligations with their newer economic responsibilities. If the law is to accommodate cost constraints, soine new approach inust be found. In Part III, I consider several possible answers and conclude that the presumption of a unitary

34. A case of this sort, Blake v. District of Columbia, No. 2623-80 (D.C. Super. Ct. June 30, 1981), is discussed in Mehlman, Rationing Expensive Lifesaving Medical Treatments, 1985 Wis. L. REV. 239, 287 (1985).

35. Becker v. Janinski, 15 N.Y.S. 675 (1891); Ricks v. Budge, 91 Utah 307, 64 P.2d 208 (1937); A. HOLDER, supra note 28, at 378; Marsh, supra note 28, at 179; Note, supra notc 33, at 938.

36. Small v. Howard, 128 Mass. 131, 135 (1880); Pike v. Honsinger, 155 N.Y. 201, 209-10, 49 N.E. 760,762 (1898); Becker, 15 N.Y.S. at 676.

37. Fuchs, supra note 1, at 1575; Thurow, supra note 15, at 611-12.

38. For a more detailed description of stratified scarcity in medical care today, and an argument that holding physicians legally liable for concomitant substandard care is at least sometimes morally unacceptable, sec Morrein, Commentary: Stratified Scarcity and Unfair Liability, 36 CASE W. RES. L. REv. 1033 (1986). 
standard of care should be rebuttable by evidence of unavoidable economic constraints.

\section{FisCAL Versus Fiduciary REsponsibILITIES}

The current legal insistence upon an essentially uniform standard of basic medical care arises largely from the fiduciary nature of the physician-patient relationship. The enormous miportance of the patient's imterest in good health care, combined with his increased dependency during serious illness and his general inability to ineet his own inedical needs, renders him highly vuhierable to the physician's superior knowledge, skill, and consequent power in the relationship. The patient must be able to repose confidence in his physician, beheving that the latter will be not ouly professionally competent but also devoted to his interests. Otherwise, it would be difficult for the patient to generate the trusting cooperation so essential to good health care. ${ }^{39}$ To permit physicians routinely to balance their patients' interests against others' economic welfare could devastate this fiduciary relationship..$^{40}$ And yet as we have seen, the pressures upon the inedical community to contain costs are inescapable.

It is teinpting at this poimt to hope that we might honor both values-physicians' special obligations to patients and society's need to conserve resources-by requiring that people other than the physician pursue the economic goals, leaving physicians free to focus solely on their patients' interests. If, for example, a hospital's cost containment guidelines or utilization committee decisions literally preclude the pliysician from providing overly expensive care, then he can legitimately claim that others, not he, are balancmg his patients' welfare agamst others' financial concerns. His fiduciary commitment would thus remain unsullied. ${ }^{41}$

Unfortunately, this answer is hopelessly madequate. It begs the

39. Curran \& Moseley, supra note 30, at 76; Feldman \& Ward, Psychotherapeutic Injury: Reshaping the Implied Contract as an Alternative to Malpractice, 58 N.C.L. REV. 63, 76-85 (1979); Mechanic, The Transformation of Health Providers, HEALTH AFF., Spring 1984, at 65, 67-68.

40. Blumstein, Rationing Medical Resources: A Constitutional, Legal, and Policy Analysis, in 3 President's COMM'N For the STUdy of Ethical Problems in Medicine and Biomedical and Behavioral Research, Securing ACCess to Health Care 349, 389-90 (1983) [hereinafter PRESIDENT'S COMM'N]; Marsh, supra note 28, at 176-78.

41. R. VEATCH, A THEORY OF MEDICAI ETHICS (1981); Levinsky, supra note 1. Veatch, for exaniple, behieves we should inake it "impossible for the physician to order the sixth stool guaiac." Id. at 285 . He is referring to a study by Neuhauser \& Lewicki, What Do We Gain From the Sixth Stool Guaiac?, 293 NEw ENG. J. MED. 226 (1975), which showed that in screening for colon cancer, the inarginal cost of the sixth serial guaiac test is $\$ 50$ million for each new cancer detected. Veatch argues that the physician should not be responsible for decisions to eliminate interventions of even infinitesimal benefit on grounds of costs-others must niake such decisions. See also Veatch, DRGs and the Ethical Reallocation of Resources, HASTINGS CENTER REP., June 1986, at 32. 
basic legal question: Should the law permit any health care provider, whether physician or hospital, to adjust its standards of care according to patients' financial resources?

The proposal is also medically untenable. Aside from the practical fact that such guidelines would have to be virtually infinite in length and complexity to cover every possible situation, the very notion of such detailed guidance is based on an erroneous view of medicine. It presupposes that medicine can be practiced by "cookbook" or coinputer, with a simple application of universal rules to individual cases. Yet surely medicine cannot be practiced in this manner. It may be possible to produce specific guidelines in limited areas-for example, an insurance company may autliorize only a limited number of hospital days for each particular diagnosis, or a hospital may restrict physicians' access to the most expensive teclınologies. ${ }^{42}$ But such gnidelines cannot extend into all the daily details of medical care; nor can they be rigid and inviolable, such as "always clioose this cheaper antibiotic for this type of infection." Medical science is imperfect and incomplete, and the individual human body and its maladies can defy even the safest generalizations. Good liealth care requires the clinical judgment that arises not only from scientific generalizations but also from experience, from knowledge of things that liave not been quantified into scientific data, and indeed even from professional intuition. ${ }^{43}$ Tlrus, while hospitalization is ordinarily not warranted for a complete series of gastroenterologic examinations, a frail, elderly patient may well require inpatient observation. No guidelines can adequately aceount for individual variation or for clinical uncertainty, and any hospital or corporate administrator who purported to tell the physician precisely what interventions are (economically) warranted for

42. Some hospitals, for example, have established a two-tiered pharmacy system in which the most expensive medications can only be ordered with the concurrence of a physician in the appropriate subspecialty. Thus, to order a third-generation cephalosporin antibiotic, which could cost up to $\$ 2000$ for an adult's 10-day course, the physician would need to consult the infectious disease service. In like manner, the hospital's pharmacy might not stock certain expensive drugs, thus effectively precluding the physician from ordering them for his hopitalized patients. Recently Blue Cross and Blue Shield Association, with the cooperation of the American College of Physicians and the endorsement of several other national medical groups, have issued guidelines on the use of such common diagnostic tests as chest $\mathrm{x}$-rays, electrocardiograms, urinalyses, complete blood counts, and throat cultures. See Page, Blues Crack Down on Test Pay, Am. Med. News, Apr. 17, 1987, at 9, col. 2; Ver Berkmoes, Blues, ACP Offer Diagnostic Test Guides, Am. Med. News, Apr. 10, 1987, at 9, col. 2; James, Blue Cross Plans Coverage Limits on Many Tests, Wall St. J., Apr. 1, 1987, at 31 , col. 2.

43. See Eddy, Variations in Physician Practice: The Role of Uncertainty, HEALTH App., Summer 1984, at 74; Gorovitz \& MacIntyre, Toward a Theory of Medical Fallibility, 1 J. MED. \& PHIL. 51 (1976); Morreim, Cost Containment: Issues of Moral Conflict and Justice for Physicians, 6 TheORETICAL Med. 257 (1985); Thurow, supra note 15; Wartofsky, Clinical Judgment, Expert Programs, and Cognitive Style: $A$ Counter-Essay in the Logic of Diagnosis, 11 J. MED. \& PHI. 81 (1986). 
each patient would literally be practicing inedicine in tlie physician's stead (without a license!).

Cost containment guidelines, then, must leave considerable clinical freedoin for the physician to exercise professional judgment. Yet the very flexibility necessary for good health care will likewise ensure tliat the physician is caught between conflicting obligations. If cost guidelines require the plyysician to reduce overall the number of days his patients are hospitalized, for example, or generally to order fewer expensive procedures, lie can only achieve this goal by doing less for individual patients. The power to say "yes" in one case would carry witl it the requireinent to say "no" in soine other case. So long as the pliysician retains the power of decisioumaking necessary for good health care, he is ipso facto a key agent of resource allocation. ${ }^{44}$

This recognition of the nature of the physician's role has important implications for our jurisprudential question. Cost containment prevents physicians from maintainm their traditional, (theoretically) uncompromising commitment to their patients. This, in turn, constitutes a powerful argument that inalpractice law sliould now make some allowance for economic constraints, at least under soine circumstances. Moral fairness requires that the physician not be punislied for implementing in good faith the cost-containment responsibilities that society has imposed upon him. ${ }^{45}$ Indeed federal and state governments, liaving led the way in cost containment, arguably liave a moral duty to help reconcile the conflicts that arise when their new econonic policies undermine their traditional adherence to a unitary standard of care in medicine. However, the rules that traditionally have gnided malpractice hitigation do not ease the tension between fiduciary fairness to patients and jurisprudential fairness to physicians.

\section{II}

Traditional Legal ConcePtS

\section{A. Locality Rule}

Let us begin, then, with the locality rule. The law has long recognized that physicians must practice under a variety of resource conditions. From the late nineteenth century, the locality rule has held that it is unfair to apply "urban" standards of care to physicians practicing in outlying rural areas, who did not liave access to the greater opportunities

44. See May, On Ethics and Advocacy, 256 J. AM. MED. A. 1786 (1986); Morreim, Clinicians or Committees-Who Should Cut Costs?, Hastings Center Rep., Apr. 1987, at 45; Morreim, Physicians Face New Ethical Binds, Wall St. J., Sept. 24, 1987, at 20, col. 3.

45. Morreim, supra note 38 , at 1034 . 
for learning and practice available to their brethren in larger cities. ${ }^{46}$

The locality rule is fast disappearing as a basis on which to evaluate physicians' personal skills and knowledge. Standardized education, certification, and improved communication have largely erased the regional differences of competence within various nedical specialties. The locality standard is thus giving way to national standards both for specialists and for general practitioners. ${ }^{47}$

However, the locality rule does partly survive through soine courts' recognition that physical and fiscal resources vary froin place to place. For example, in Hall v. Hilbun, ${ }^{48}$ the Suprenie Court of Mississippi offered a "resources-based caveat" to the national standard of care: A physician's duty of care is to be appraised not only according to the nationwide level of knowledge and skill for physicians within his field, but also according to the particular level of facilities, services, and equipment available to that physician in his actual circumstances. Thus, a court inay take into account the resources of the local community when it applies a general professional standard. ${ }^{49}$

The locality rule can provide soine assistance in our search for a solution to the physician's dilemma. If a relnote village has neither a CAT scanner of its own nor access to one within a reasonable distance, then the physician will not be held at fanlt for failing to order such a test, even if it is common practice to do so elsewhere. However, the economic limits of an entire region are not our primary concern. Our focus is on the variation of resources within the same region, even the sane city. Where an nidigent patient is denied a desirable intervention because of its cost, we would have to stretch the locahity concept to apply, not to the patient's geographic location, but to his socioeconomic station.

In other words, we would have to expand the locality rule to cover both the unavailability of resources and conscious decisions to refrain from using available resources. Here, the physician forgoes an intervention not because it cannot be procured or because the patient would not benefit, but because of a priority decision that this patient's benefit would not be certain enough or substantial enough to justify depriving other, needier patients. Such a stretching of the locahity concept would not be a reasonable extension of its original meaning. Rather, it would anount to a new rule in old language, a logical equivocation. Thus, the locality rule

46. E.g., Tefft v. Wilcox, 6 Kan. 46 (1870); Small v. Howard, 128 Mass. 131 (1880); see also A. HOLDER, supra note 28, at 58-61; McCoid, supra note 28, at 569-75; Note, supra note 29, at 730-31.

47. E.g., Shilkret v. Annapolis Emergency Hosp. Ass'n, 276 Md. 187, 349 A.2d 245 (1975); Brune v. Belinkoff, 354 Mass. 102, 235 N.E.2d 793 (1968); Naccarato v. Grob, 384 Micl. 248, 180 N.W.2d 788 (1970); Hall v. Hilbun, 466 So. 2d 856 (Miss. 1985); see also A. HoLDER, supra note 28, at 59; McCoid, supra note 28, at 569-75; Note, supra note 29, at 732-41.

48. 466 So. $2 \mathrm{~d} 856,872-73$ (Miss. 1985).

49. Prosser \& KeETON, supra note 28 , at 187-88. 
cannot resolve the tensions between physicians' fiduciary obligations and tlieir economic responsibilities.

\section{B. Medical Custom}

The medical profession's standard of care is based upon the practice of the profession's members, as pliysicians liave the unusual privilege of setting their own legal standards of conduct. ${ }^{50}$ Could accepted medical custom be redefined to take into account tlie new economic constraints? To some extent the answer is "yes."

Government and corporate cost containment efforts have been necessitated at least partly because customary medical care is inflated by needless and marginal interventions. Defensive medicine, wherein pliysicians perform extra tests and procedures to ward off malpractice risks, both real and imagined, may cost the nation as much as $\$ 13.7$ billion per year. ${ }^{51}$ Further, as noted above, earlier reimbursement policies encouraged physicians to do everything that promised even the sinallest benefit for patients. ${ }^{52}$ Beyond this, the clinical routimes on which pliysicians often rely to guide tlieir management of ordinary cases are not always based on careful thought and scientific reasoning. Many of these procedures might be trimmed substantially witliout significantly reducing the quality of care. ${ }^{53}$ Indeed, professional societies and subspecialty organizations, whose consensus conferences traditionally liave aimed at disseminating new researcl into the medical community, could now begin to formulate explicit gindelines for higlı quality, yet more costconscious, care. ${ }^{54}$ Physicians in sucl gatherings imglit agree on indications for such common surgeries as hysterectomy, tonsillectomy, or prostatectomy, ${ }^{55}$ or on the routine care of uncomplicated myocardial

50. Id. at 189; Blumstein, supra note 40, at 391; Bovbjerg, The Medical Malpractice Standard of Care: HMOs and Customary Practice, 1975 DukE L.J. 1375, 1377, 1384; Havighurst, Altering the Applicable Standard of Care, LAw \& CONTEMP. ProBS., Spring 1986, at 265, 266-67; McCoid, supra note 28, at 605-09; Pearson, supra note 29, at 528; Comment, California Negotiated Health Care: Implications for Malpractice Liability, 21 SAN D1EGo L. REV. 455, 464 (1984).

51. Reynolds, Rizzo \& Gonzalez, supra note 25, at 2778; see also Bovbjerg, supra note 50, at 1397; Zuckerman, Medical Malpractice: Claims, Legal Costs and the Practice of Defensive Medicine, HEALTH AFF., Fall 1984, at 128.

52. See supra note 7 and accompanying text.

53. Eddy, Clinical Policies and the Quality of Clinical Practice, 307 NEw ENG. J. MED. 343 (1982); Wong \& Lincoln, Readyl Firel . . . Aiml: An Inquiry Into Laboratory Test Ordering, $250 \mathrm{~J}$. AM. MED. A. 2510 (1983).

54. Eichorn, Cooper, Cullen, Maier, Philip \& Seeman, Standards for Patient Monitoring During Anesthesia at Harvard Medical School, 256 J. AM. MED. A. 1017 (1986) [hereinafter Eichorn]; Fortess \& Kapp, Medical Uncertainty, Diagnostic Testing, and Legal Liability, 13 LAw MED. \& Health CARE 213, $217-18$ (1985); Mullan \& Jacoby, The Town Meeting for Technology: The Maturation of Consensus Conferences, 254 J. AM. MED. A. 1068 (1985).

55. Egdahl, Ways for Surgeons to Increase the Efficiency of Their Use of Hospitals, $309 \mathrm{NEw}$ ENG. J. MED. 1184, 118485 (1983). 
infarction. ${ }^{56}$ In sum, there are inany ways in which physicians can economize without compromising quality of care. Perhaps such trimming of medical routines offers a way out of our dilemma. Since the law refers principally to physicians' prevailing customs in order to specify the standard of care, physicians themselves could deflate that standard.

This approach has several advantages. Costs have always played at least some role in shaping medical standards of care. ${ }^{57}$ Physicians do not order a CAT scan for every headache, nor do they routinely screen for colon cancer with six serial stool guaiac tests-the sixth of which, in 1975 , cost $\$ 50$ million for each new cancer detected. ${ }^{58}$ Aside froin the dangers of false-positive diaguostic results and unwanted side effects, the marginal benefits simply may not merit their costs.

Furtherinore, the profession as a whole could adopt reduced chinical routines without offending society's egalitarian values. The more costconscious custorns would guide all patients' care, not just poor patients' care. Finally, this approach could alleviate present dangers to the fiduciary relationship. As physicians scale down their practices, patients niay likewise lower their expectations - the very expectations that partly define physicians' fiduciary duties.

Unfortunately, this apparently promising avenue is fraught with obstacles. Problems arise whether custoin shifts gradually through the actions of individual physicians or by means of collectively written consensus guidelines.

\section{Gradual Shift in Custom}

Judicial rehiance on custom to specify the standard of care has never been absolute. Courts permit deviations from custom where evidence shows new medical techniques to be superior to the old; they also permit noncustoinary routes to the same medical goals by accepting the practices of "respectable minorities." 59 On occasion, they even require a profession to change its outdated or inadequate custoins. ${ }^{60}$

This flexibility is of limited value here, however. All of these

56. Baughman, Hutter, DeSanctis \& Kallman, Early Discharge Following Acute Myocardial Infarction: Long-Term Follow-Up of Randomized Patients, 142 ARCHIVES INTERNAL MED. 875 (1982); Fuchs \& Scheidt, Improved Criteria for Admission to Cardiac Care Units, 246 J. AM. MED. A. 2037 (1981).

57. Fuchs, supra note 1, at 1576.

58. Neuhauser \& Lewicki, supra note 41 , at 226.

59. Schuck, Malpractice Liability and the Rationing of Care, in President's COMm'N, supra note 40 , at 413; see also A. HoLDER, supra note 28 , at $47-48$; Blumstein, supra note 40 , at 391 ; McCoid, supra note 28, at 565.

60. E.g., Toth v. Community Hosp., 22 N.Y.2d 255, 239 N.E.2d 368, 292 N.Y.S.2d 440 (1968); Helling v. Carey, 83 Wash. 2d 514, 519 P.2d 981 (1974); cf. The T.J. Hooper, 60 F.2d 737 (2d Cir. 1932) (tugboat held unseaworthy because it lacked radio equipment to receive storm warnings, even though use of such equipment was not wide-spread). 
allowances are predicated upon the principle that the interests of the patient are paramount. Where courts allow deviations from custom, they generally insist that the deviations improve, or at least preserve, the basic level of care. ${ }^{61}$ While they might allow physicians to eliminate hiterally useless customs and thereby avert needless iatrogenic imjuries, courts are quite unlikely to endorse a cutback that actually reduces the quality of tlie patient's care in order to benefit, not the patient, but the economic mterests of some third party. ${ }^{62}$ Even small diminutions of care could be legally perincious. Where a diagnostic or therapeutic intervention is eliminated because it lielps too few patients to warrant tlie cost, those patients who would actually have been helped by that intervention might cite tlie "Ioss of a cliance" doctrine ${ }^{63}$ to argue that they have been treated negligently. The elimination does not liarm most patients, and it even benefits some by avoiding iatrogemic injuries or diagnostic false positives. Nevertheless, a few patients can argue tliat, liad tlie (more costly) traditional custom been followed, their own illness would lave been better diagnosed and treated. ${ }^{64}$

Thus, the lone pliysician who dares to defy custom in the name of costs is likely to incur substantial legal risk. ${ }^{65}$ The problem is exacerbated for those physicians wlio attend tlie poor. Even a successful general deflation of custom would leave these physicians legally vulnerable. Because plysicians who treat indigents have substantially fewer resources than most pliysicians for their patients' care ("stratified scarcity"), their services sometimes will still be literally substandard-tliat is, below the level available to the majority of the population. So long as the law identifies the standard of care according to prevailing custom, and so long as these pliysicians are economically precluded from delivering that

61. Note, supra note 27 , at 1018 .

62. Kapp, Legal and Ethical Implications of Health Care Reimbursement by Diagnosis Related Groups, 12 LAW MED. \& HeAlTH CARE 245, 249-50 (1984).

63. E.g., Waffen v. Department of Health \& Human Servs., 799 F.2d 911 (4th Cir. 1986) (recognizing cause of actiou for "loss of a substantial possibility of survival"); DeBurkarte v. Louvar, 393 N.W.2d 131, 139 (Towa 1986) (jury could award dannages for pain and suffering from "reduction in [patient's] chance of survival"); Valdez v. Lyman-Roberts Hosp., 638 S.W.2d 111, 116 (Tex. Ct. App. 1982) (hospital could be leld liable for depriving patient of chance of survival, however remote).

64. Suppose, for exainple, that a new hospital policy discourages physicians from obtaiuing the chest $\mathrm{x}$-rays which previously had been routinely obtained for all patients admitted to the hospital. Suppose further that a patient has early lung cancer that would have beeu detected by this routine test but was not diagnosed until much later, due to the cost-oriented ehmination of this routine. This patient might argue that her chance of survival was substantially diminished by the curtailment of custom. This argnment cannot be made, for example, by the patient who did not receive magnetic resonance imaging as a "routine admission procedure," for this latter test has never been a "routine" of admission. The difference is not so much one of medical substance, as of history. One can only claim that duties of custom lave been breached where there was a custom in the first place.

65. Bovbjerg, supra note 50, at 1377; Havighurst, supra note 50, at 269. 
level, they will be systematically at risk for malpractice liability. The law will expect them to perform the impossible.

\section{Explicit Consensus Guidelines}

The medical profession might avoid some of these problems by revising its customs through explicit consensus guidelines ${ }^{66}$ rather than tlirougli liazardous increments of individual pliysicians. Where the profession as a wliole or in prestigious groups declares that particular interventions, thouglı hitherto standard, are really of little or no value, ${ }^{67}$ the individual pliysician can feel more confident in trimming lier own practices. Slie could point to the professional consensus in the event lier conduct is cliallenged in court.

Significant problems remain, lowever. If such guidelines are desigued mainly by leaders of the profession wlio practice at well-funded tertiary care centers, their cost-conscious new standards miglit still be too ricl for private pliysicians practicing im economically leaner circumstances. Even where the guidelines are acceptable to "mainstream" medicine, they may still set an unreahistic standard for pliysicians who attend the poor. ${ }^{68}$

Sucl exphicit guidelines could also render the position of the indigents' pliysician more precarious in the event of a lawsuit. It is difficult enough for a pliysician to measure up to the "anybody's guess" medical standards that emerge from competing expert witnesses in a courtrooin. It would be nearly impossible for her to defend an economically unavoidable deviation from a set of written, already cost-conscious standards establislied by her better-funded colleagues. ${ }^{69}$

Thus, physicians cannot extricate themselves froin tlieir conflicting

66. See, e.g., Cebul \& Poses, The Comparative Cost-effectiveness of Statistical Decision Rules and Experienced Physicians in Pharyngitis Management, 256 J. AM. MED. A. 3353 (1986); Consensus Conference, Fresh-Frozen Plasma: Indications and Risks, 253 J. AM. MED. A. 551 (1985); Eichorn, supra note 54; Palmer, Kane, Churchill, Goldman \& Komaroff, Cost and Quality in the Use of Blood Bank Services for Normal Deliveries, Cesarean Sections, and Hysterectomies, 256 J. AM. MED. A. 219 (1986).

67. See, eg., James, supra uote 42; Schwartz, The Role of Professional Medical Societies in Reducing Practice Variations, HeAlTh AfF., Summer 1984, at 90; Ver Berkmoes, supra note 42.

68. Technologies such as lithotripsy and magnetic resonance imaging are rapidly becoming commonplace, and soon will be part of standard care. For public hospitals that cannot afford such equipment, however, this standard may be unattainable. For further examples, see Morreim, supra note 38, at 1037-39; see also Hombein, The Setting of Standards of Care, 256 J. AM. MED. A. 1040, 1041 (1986) (voicing coucern that technological advances will be used to set a profession-wide standard of care).

69. There is also a danger that such gnidelines could be taken too literally. May, Consensus or Coercion, 254 J. AM. MED. A. 1077 (1985). While every physician knows that good medicine cannot be practiced by "cookbook," it may nevertheless be tempting to suppose that so long as one does everything recommended by the protocol, he is legally even if not medically secure-even though the patient's condition may require further care. Reciprocally, and just as dangerously, the physician might be tempted to suppose that he must do everything recommended in the guideline, whether or 
responsibilities, nor avert the prospect of unfair legal liability, simply by deflating their customs. Physicians are allowed to set their own standards only so far as they uphold the existing quatity of basic care. While the wealthy may receive more than the minimum, the poor may not receive less. This method of defining the standard of medical care, like the locality rule, fails to protect the economically beleaguered physician. There remain two other legal concepts that introduce some flexibility into the standard of care and that might provide a sanctuary. They share a common defect and will therefore be considered together.

\section{C. "Respectable Minority" and "Accepted Practice"}

The law does not require slavish adherence to custom. A medical method needn't always be prevalently practiced or widely approved in order to be legaily acceptable. To allow for the diversity of approaches that inevitably arises out of scientific and practical uncertainties, and, to permit fruitful growth and change im medical knowledge, the law sometimes accepts noncustomary practices. Where alternative methods are accepted by a mimority of reputable plysicians, then their use is not substandard, nor inalpractice. ${ }^{70}$ For example, the acceptable surgical treatinent of breast cancer could be radical or modified radical mastectomy, or lumpectomy, each with varying options for accompanying radiation or chemotherapy.

Several commentators liave suggested that this concept may offer a suitable avenue for incorporating economic considerations into the standard of care. ${ }^{71}$ If he can demonstrate that a respectable minority of physicians provides less costly health care, an individual physician may be able to avoid civil hability for his own cost-conscious practices.

More generally, soine legal scholars have criticized the law's reliance upon custom to specify the content of the standard of care. In their view, conformity to popular procedure is too often promoted for its own sake, regardless of whether those practices advance the desired medical outcomes or serve other values such as fiscal efficiency. Salutary changes may gain acceptance too slowly, while inappropriate practices may disappear too slowly. ${ }^{72}$

A preferable approach, according to J.H. King and others, is to look not at what physicians typically $d o$, but at what the profession approves

not the patient needs it. The resulting useless interventions could cause not only needless iatrogenic injuries but also a further escalation, not a diminution, of health care expenditures.

70. Chumbler v. McClure, 505 F.2d 489, 492 (6th Cir. 1974); A. HoLDER, supra note 28, at 47-48; Blumstein, supra note 40, at 391; McCoid, supra note 28, at 565.

71. Blumstein, supra note 40 , at 392; Schuck, supra note 59, at 413.

72. Bovbjerg, supra note 50, at 1377-78, 1394-95; Furrow, supra note 32, at 14; King, supra note 27 , at 1237 . 
as good practice. ${ }^{73}$ This "accepted practice" approach would seek from an expert witness his considered judgment concerning the profession's reasonable expectations for its members, rather than his empirical "guesstimate" of a practice's popularity. ${ }^{74}$ Because this approach is so much less dependent on preserving the status quo, it is said to be better suited than "prevailing custom" to incorporate considerations of costeffectiveness while maintaining high standards of quality. ${ }^{75}$

In order to be of real assistance in the most difficult cases, the "respectable minority" and "accepted practice" rules would have to go beyond merely stating that it is acceptable for physicians to eliminate utterly useless or highly marginal interventions on economic grounds. That sort of change is already permitted. These rules would have to embrace the further idea that it is acceptable actually to reduce the quality of health care-particularly that provided to the poor-in order to conserve resources. Yet existimg malpractice law effectively precludes this very step. Each method of establishing the standard of care-custom, accepted practice, and respectable minority-is sanctioned only insofar as it implements the same underlying principle: The standard of care is to be defined by reference to the medical welfare of the patient, and all patients are entitled to receive at least "ordinary and reasonable" care. ${ }^{76}$ Therefore, any minority who wished to drop below this minimum level ipso facto would not be "respectable." Further, the profession as a whole would be unable to call such a practice "medically approved" no matter how economically justifiable it might be. Thus, the latter two legal concepts fail, just like the previous ones.

\section{Informed Consent}

The informed consent, or full disclosure, principle aims to enhance patients' control over their own health by maximizing their knowledge. ${ }^{77}$ The principle is founded on the fiduciary requirement that physicians try to minimize the inequality of power mherent in the physician-patient relationship. It requires the physician to provide enough infornation for the patient to make an inforined and intelligent decision about whether to undergo a particular course of treatment. Accordingly, some suggest that physicians ought to inforn their patients about all medically reasonable options, even those that are not economically available through

73. King, supra note 27 , at 1236.

74. Id. at $1241-43$.

75. Id. at 1252 .

76. See supra note 28 and accompanying text.

77. Canterbury v. Spence, 464 F.2d 772, $781-82$ (D.C. Cir.), cert. denied, 409 U.S. 1064 (1972); Cobbs v. Grant, 8 Cal. 3d 229, 242-43, 502 P.2d 1, 9-10, 104 Cal. Rptr. 505, 513-14 (1972); Miller v. Kennedy, 11 Wash. App. 272, 522 P.2d 852 (1974), affd, 85 Wash. 2d 151, 530 P.2d 334 (1975). 
third party coverage. ${ }^{78}$ In this way, the patient has the option to pay for the additional health care out of his own pocket, or to petition those who hold the purse strings. In principle, at least, the physician can thereby both enhance patient autonomy and honor his fiduciary promise to pursue his patient's interests above all others'.

As I have shown elsewhere, ${ }^{79}$ this superficially plausible solution could harm rather than enhance the trust between patient and physician. In certain instances, the principle could require the physician-unavoidably a pivotal agent of allocation decisions - to inforn the patient that the physician himself is withholding some desirable imtervention because of cost or of other patients' greater need. Where the patient lacks the money or political influence to secure the preferred care, it will hardly enhance her autonomy or her trust simply to tell her that her care is inferior. ${ }^{80}$

An extreme reliance on tlie inforned consent principle might invite us to embrace private contracting, wherem the patient would exphicitly agree to accept lesser care $\mathrm{m}$ exchange for smaller premiums. However, as we will discover in Part III below, in the case of the poor such arrangements would be botll morally and legally unconscionable. ${ }^{81}$

This is not to say that full disclosure is unimportant. Fiduciary obhgations and the moral value of respect for personal autonomy may

78. Abrams, Patient Advocate or Secret Agent?, 256 J. AM. MED. A. 1784 (1986); Blumstein, supra note 40, at 389-90; Council on Ethical and Judicial Affairs, Recent Opinions of the Council on Ethical and Judicial Affairs, 256 J. AM. MED. A. 2241 (1986); Kapp, supra note 62, at 251; Marsh, supra note 28, at 177-78; Rust, Review System May Yield More Suits for Undertreatment, Am. Med. News, July 11, 1986, at 36. According to this approach, physicians should inform patients not ouly about services that are not covered by third-party payers, but also about payers' utilization review policies and efforts to curtail ongoing services. See Hershey, supra note 23, at 61 .

79. Morreim, supra note 38, at 1043-44.

80. A further problein may arise. Each time the physician says, " $X$ is desirable for you but I have decided not to offer it to you," the patient may wish to ask, "Can't you make an exception for me?" At this point, the physician has a choice. If he adheres to his cost-containment policy, he essentially must tell the patient, "You don't merit an exception." On the other hand, if he frequently inakes exceptions, he is effectively abdicating cost containinent for, as noted above, costs can only be contained through mdividual physicians' regular decisions to forego interventions in particular circumstances.

Further, if the scarcity that proinpted the cost-containment pressures is genuine, then each physician who refuses to make such resource allocation decisions will place unfair burdens on other physicians and their patients. His unwillingness to say "no" to his own patients will mean that they must say "no" to their patients more often. The hospital, to avert such a situation, may eventually discipline the physician or ask him to practice elsewhere. See Hershey, supra note 23, at 61-62.

Even where the patient ean pay for extra care, the informed consent approach can engender a counter-fiduciary incentive. Under constant pressure to limit his spending, the physician may be tempted to say, "This intervention is desirable but not covered by your insurance," as often as possible to those patients whom he knows ean pay for the extra care theinselves. In other words, it nay be tempting to exercise his climical discretion less favorably for well-to-do patients than for others. As the wealthy would thereby contribute inore of their own money to health care, more resources would be available to care for the poor.

81. See infra text accoinpanying notes 149-57. 
require that information be disclosed even where adverse consequences may result. I offer only the more modest conclusion that the informed consent primciple does not help us to reconcile the tension between the two precepts, fairness to patients and fairness to physicians. Far from enhancing the fiduciary relationship, we have seen that it can, at least in principle, do quite the reverse. ${ }^{82}$

\section{E. Equal Protection}

Perhaps the rule of equal protection can guide us. After all, if we allow physicians to cite cost constraints as a defense to malpractice, we are admittedly varying according to wealth the threshold point below which we define tortious deviations from the duty of care. That is, we would declare that some particular injury is a tort if perpetrated upon a wealthy patient (to whom the physician owed a greater duty of care), but not a tort if the victim is mdigent. The latter would thereby have lesser access to legal remedies for his or her injuries. If this were found to be an infrimgement of equal protection, we might have an answer to our jurisprudential query.

The question is somewhat novel. Although current literature and hitigation address equal protection questions in related topics of health law, neither specifically inquires whether standards of care, and thereby access to compensation for one's medical imjuries, may permissibly vary according to patients' financial resources. There are two such related topics: states' malpractice tort reforms and government-sponsored rationing of health care resources. We will explore each briefly. First, however, we must sketch the basic elements of the equal protection principle.

Equal protection ${ }^{83}$ requires that states treat people in similar circumstances similarly. ${ }^{84}$ That is, the state may not treat citizens differently unless there is sufficient reason to do so. "Sufficient reason," in turu, depends on the nature of the interest at stake. Where fundamental rights or interests are involved, ${ }^{85}$ or where "suspect classifications" are

82. McPhee, supra note 1, at 604 ; Stone, supra note 27 , at 312.

83. "No State shall ... deny to any person ... the equal protection of the laws." U.S. CoNST. amend. XIV, §1.

84. Tussman \& tenBroek, The Equal Protection of the Laws, 37 CALIF. L. REV. 341, 344 (1949); Blumstein, supra note 40, at 379-82.

85. These include, for example, the right to vote, freedom of expression and association, fairness in criminal proceedings, and the right to interstate travel. J. NowAK, R. RoTUNDA \& J. Young, Constrtutional LAw 457-61 (2d ed. 1983); see, e.g., Shapiro v. Thompson, 394 U.S. 618 (1969) (fundamental right to travel interstate); Harper v. Virginia Bd. of Elections, 383 U.S. 663 , 667-69 (1966) (fundamental right to vote); cf. Sibley v. Board of Supervisors, 462 So. 2d 149, 155 (La. 1985) (right to sue in tort to recover for personal injuries held not a fundamental right under federal or state constitution), on reh'g, 477 So. 2d 1094, on remand, 490 So. 2d 307 (La. App.), cert. denied, 496 So. 2d 325 (La. 1986). 
einployed ${ }^{86}$ the Supreme Court will apply "strict scrutiny." In such a case, the Court will not presume the state's action to be valid, but will require that any invasion of a fundamental right or use of a suspect classification be justified by a "compelling" state interest. ${ }^{87}$

In contrast, where general economic and social interests are at stake, the Court's "rational basis" test requires only that the statute's classification-that is, its basis for treating some citizens differently-be "rationally related to a legitimate state interest." ${ }^{88}$ So long as the classification is not clearly arbitrary or irrational, and so long as the state's aim is not plainly unacceptable, the statute is likely to satisfy equal protection requirements.

The rational basis test is normally quite deferential. The Court has, on occasion, been willing to accept any conceivable explanation to sustain the rationality of economic and social legislation. ${ }^{89}$ However, the Court has at times resisted the rigidity of its two-tiered equal protection jurisprudence. In applying the rational basis test, it has sometimes examined the rationality of a challenged classification in soine detail.$^{90}$ In other cases, the Court has refused effect to laws while ostensibly applying its traditional rational basis test. ${ }^{91}$ Finally, in the 1mid-1970's, the Court explicitly adopted an intermediate level of equal protection scrutiny in cases involving gender classifications: the government's action "inust serve imiportant governmental objectives and inust be substantially related to achievement of those objectives." ${ }^{22}$ This imtermediate review may apply in other cases where important, though not necessarily "fundamental," interests are at stake, or where the criteria of classification are sensitive, if not "suspect." 93

86. These include, for example, race, religious or political beliefs, and national origin. J. NowaK, R. RotuNDA \& J. YouNG, supra note 85, at 357, 531, 1067-68; see, e.g., Loving v. Virginia, 388 U.S. 1 (1967) (classification by race); see also Sibley, 462 So. 2d at 155.

87. Palmore v. Sidoti, 466 U.S. 429, $432-33$ (1984); Graham v. Richardson, 403 U.S. 365, $375-$ 76 (1971); Sibley, 462 So. 2d at 155; see also Mehlman, supra note 34, at $260 \mathrm{n.110}$ (distinctions in allocation of lealth care based on social worth of patients may violate equal protection).

88. New Orleans v. Dukes, 427 U.S. 297, 303 (1976).

89. J. NowAK, R. Rotunda \& J. Young, supra note 85, at 530; L. TRIBE, AMERICAN Constitutional LAw 996 (1978). The Court is prepared to use its own imagination to supply the rational explanation. See, e.g., Williamson v. Lee Optieal, 348 U.S. 483, 489 (1955) ("Evils in the same field may be of different dimensious and proportions, requiring different remedies. Or so the legislature may think.")

90. See, e.g., New York City Transit Authority v. Beazer, 440 U.S. 568 (1979); Charlotte v. Local 660, 426 U.S. 283 (1976); cf. Johnson v. Robison, 415 U.S. 361, 374-75 (1974), which quotes the less deferential formulation of the traditional equal protection rule found in Royster Guano Co. v. Virginia, 253 U.S. 412, 415 (1920)(the classification "must rest upon some ground of difference having a fair and substantial relation to the object of the legislation").

91. See, e.g., United States Dep't of Agriculture v. Moreno, 413 U.S. 528, 553-54 (1973); Reed v. Reed, 404 U.S. 71, 76-77 (1971).

92. Craig v. Boren, 429 U.S. 190, 197 (1976).

93. L. TRIBE, supra note 89 , at 1089-90. The Kansas Supreme Court las identified this 
With this background, then, let us consider the case law and literature on tort reform and resource rationing.

\section{Tort Reform}

As the "n1alpractice crisis" of the mid-1970's peaked, niany states instituted tort reforms designed to curb the high costs of nualpractice litigation and defensive medicine that had contributed to the high cost of health care. These reforms also addressed the increasing cost or unavailability of liability insurance, which had forced a nuniber of physicians to withdraw from practice. The reforms included mandatory arbitration panels, restrictions on attorneys' contnigency fees, periodic paynients of future damages, alterations in collateral source rules, and changes in statutes of limitation. ${ }^{94}$ For illustrative purposes, I will focus particularly upon legislative attenipts to limit plaintiffs' recovery of danıages. North Dakota, for example, tried to limit total recovery for all daniages to $\$ 300,000,{ }^{95}$ while Califormia applies its $\$ 250,000$ cap only to noneconomic damages. ${ }^{96}$ While all of these reforms have been challenged on a variety of grounds, the equal protection reasoning apphied to these damage limits is particularly relevant to our own inquiry.

In assessing equal protection challenges to tort reform acts under either the federal or state constitutions, state courts have eniployed varying levels of scrutimy. ${ }^{97}$ While virtually all have agreed that the right to

intermediate level as "heightened scrutiny," distinguishing it from the rational basis test by noting that a classification subject to heightened scrutiny must "substantially further a legitimate legislative purpose," rather than merely bear a rational relationship to such a purpose. Farley v. Engelken, 241 Kan. 663, 667, 740 P.2d 1058, 1062 (Kan. 1987).

94. See generally Robimson, supra note 26 , at 5 .

95. Ameson v. Olson, 270 N.W.2d 125, 136 (N.D. 1978) (limitation on damages held to violate equal protection clauses of fourteenth amendment and state constitution, in the absence of a proven cost or availability crisis). The Indiana Supreme Court upheld a flat cap of $\$ 500,000$ on all medical malpractice damages, both economic and noneconomic. Johnson v. Saint Vincent Hosp., 273 Ind. 374,404 N.E. 2 d 585 (1980). A Federal district court rejected Texas's similar cap of $\$ 500,000$ for all damages. Waggoner v. Gibson, 647 F. Supp. 1102 (N.D. Tex. 1986).

96. CaL. Civ. Code $\S 3333.2$ (West Supp. 1987). Louisiana initially embraced a flat cap applicable to all damages, but court review and subsequent legislation resulted in a $\$ 500,000$ cap applicable only to non-medical damages. See Sibley v. Board of Supervisors, 462 So. 2d 149, 155 (La. 1985), on Teh'g. 477 So. 2d 1094, on remand, 490 So. 2d 307 (La. App.), cert. denied, 496 So. 2d 325 (La. 1986); 1985 La. Acts 239, $\$ 1$ (codified at LA. REv. STAT. ANN. $\S 40: 1299.39$ (B) (West Supp. 1987)). Florida's $\$ 450,000$ cap on noneconomic damages was struck down by the Florida Supreme Court not on equal protection or due process grounds, but on the ground that it violated malpractice victims' constitutional right to access to courts without providing a reasonable alternative benefit or sliowing an overpowering public necessity. Smith v. Department of Ins., 507 So. 2d 1080, 1087-89 (Fla. 1987).

97. In addition to the three levels of scrutiny applied by the Supreme Court, states are free to develop more stringent standards when interpreting their own constitutions. See J. NowaK, R. Rotunda \& J. Young, supra note 85, at 21 (citing PruneYard Shopping Center v. Robins, 447 U.S. 74 (1980)); see also, e.g., Farley v. Engelken, 241 Kan. 663, 668-70, 740 P.2d 1058, 1063-64 
full recovery for one's injuries is not a "fundamental right,"98 courts have disagreed over the legal significance of statutory distinctions between inedical and noninedical tort victims, and between inedical and nonmedical tortfeasors. The Supreine Court of Indiana, for exainple, invoked the "rational basis" test to rule that these classifications were rationally related to the legitimate state objective of protecting citizens' health by preventing a reduction in health care services. ${ }^{99}$

In contrast, other courts have ruled that the right to redress is nevertheless an important right, the infringenent of which requires at least intermediate scrutiny. These courts have ruled that caps on recovery deny equal protection because they unfairly and arbitrarily place special burdens on victims of inalpractice injury and provide special benefits for inalpractice tortfeasors. ${ }^{100}$ Linmited recovery laws have also been held to place unfair special burdens on the 1nost seriously injured inalpractice victims. ${ }^{101}$ Such classifications are therefore not sufficiently related to legitimate state aims to pass constitutional inuster.

These cases show that the courts' interpretations of equal protection in medical care are elastic and variable, and that at least soine courts are willing to declare that unequal access to reinedies for inalpractice injuries is a denial of equal protection. However, these cases are only partly relevant to the focus of this Article. In asking whether the law ought to

(1987)(rejecting federal "rational basis" test in favor of "heightened scrutiny" under state constitution); Sibley, 477 So. 2d at 1107 (adopting "unitary" equal protection standard).

98. Waggoner, 647 F. Supp. at 1106; Sibley, 462 So. 2d at 155; Carson v. Maurer, 120 N.H. 925, 931-32, 424 A.2d 825, 830 (1980).

99. Johnson, 273 Ind. at 392-93, 404 N.E.2d at 597 (1980); see also Fein v. Permanente Medical Group, 38 Cal. 3d 137, 162, 695 P.2d 665, 682-83, 211 Cal. Rptr. 368, 385-86, appeal dismissed, 106 S. Ct. 214 (1985); American Bank \& Trust Co. v. Community Hosp., 36 Cal. 3d 359, 373, 683 P.2d 670, 679, 204 Cal. Rptr. 671, 680 (1984).

100. Waggoner, $647 \mathrm{~F}$. Supp. at 1106 (invoking a "rational relationship test with due process underpinnings" and arguing that its application "is not 'an all but certain indication of validity' for malpractice statutes"); Wright v. Central du Page Hosp. Ass'n, 63 Ill. 2d 313, 329-30, 347 N.E.2d 736, 743 (1976) (statutory cap of $\$ 500,000$ on medical malpractice damages held arbitrary in violation of equal protection); Farley, $241 \mathrm{Kan}$. at 670-72, 740 P.2d at 106466 (applying "heightened scrutiny" to overturn statute abrogating collateral source rule in inalpractice actions); Carson, 120 N.H. at 931-32, 944, 424 A.2d at 830, 836 (explicitly rejecting a "rational basis" test in favor of "substantial relation" analysis and finding statute arbitrarily and unreasonably discrinninated in favor of health-care providers); Arneson v. Olson, 270 N.W.2d 125, 133-36 (N.D. 1978) (rejecting "rational basis" in favor of intermediate-level scrutiny and holding that singling out inalpractice claims for limitation violates equal protection); Sinon v. Saint Elizabeth Medical Center, 3 Ohio App. 3d 164, 167, 355 N.E.2d 903, 906 (1976) (inedical malpractice statute violated equal protection by conferring benefits on inedical malpractice defendants unavailable to other tort victims). This particular equal protection issue is becoming inoot in inany states as tort reforms are broadened to cover civil actions generally, not just malpractice suits. See Rust, supra note 26. For a useful summary of many of these rulings on tort reform, see Robinson, supra notc 26, at 20-21.

101. Waggoner, 647 F. Supp. at 1106; Wright, 63 Ill. 2d at 327-28, 347 N.E.2d at 741-43; Carson, 120 N.H. at 941-42, 424 A.2d at 837; Ameson, 270 N.W. 2d at 136; Duren v. Suburban Conmunity Hosp., 24 Ohio Misc. 2d 25, 30, 482 N.E.2d 1358, 1363 (1985). 
permit standards of care to vary according to patients' financial resources, our distinction is between poor and wealthier victims of medical practice rather than between medical and nonmedical litigants. Because the classification is different, the implications for equal protection may also differ. These imphications will be discussed below, after we consider the related issue of resource rationing.

\section{Rationing of Health Care Resources}

May the government curb its own health care costs by reducing its benefits for the mdigent or by rationing expensive lifesaving technologies? The consensus of the relatively sparse hiterature is that it may. ${ }^{102}$ Health care, like other welfare assistance, is not a fundamental right, ${ }^{103}$ except perhaps for prisoners who cannot secure health care for themselves. ${ }^{104}$ Barring discrimination on racial, ethnic, or retigious grounds, the government is generally free to create such programs as it wishes, to serve whom it pleases, and to alter or reduce the distribution of benefits. ${ }^{105}$ Exercise of this discretion will generally be upheld, even though the resulting programs may have a differential impact on particular racial groups or socioeconomic classes. ${ }^{106}$

Where a program has created "entitleinents," or where reductions of benefits would adversely affect important interests such as welfare or housing benefits, due process requirements may apply. ${ }^{107}$ These requirements concern only the adequacy of prior notification given to existing beneficiaries and the opportunity given those beneficiaries to challenge

102. See Blumstein, supra note 40 , at 367,374 (concluding that rationing as broad policy would not violate due process); $c f$. Mehlman, supra note 34 (proposing guidelines for evaluating particular rationing plans); Rosenblatt, Health Care Reform and Administrative Law, 88 YALE L.J. 243, 286305 (1978) (proposing structural due process model to govern the cutting of medical benefits).

103. Blumstem, supra note 40, at 380 (discussing Harris v. McRae, 448 U.S. 297, 318 (1980) (medical care not a fundamental interest) and Maher v. Roe, 432 U.S. 464, 469 (1977) (same)).

104. Estelle v. Gamble, 429 U.S. 97, 104-05 (1976) (indifference to prisoner's serious injury or illness constitutes cruel and unusual purishment under eighth amendment).

105. Blumstein, supra note 40 , at 367,374 . The Supreme Court recently reinforced this reasoning in Alexander v. Choate, 469 U.S. 287 (1985). Facing serious deficits in its Medicaid program, the Teunessee legislature voted in 1980 to reduce from 20 to 14 the number of days of hospitalizatiou per ycar that it would provide for eligible citizens. In a class action, Medicaid recipients sued for declaratory and injunctive rehef, arguing that because the handicapped would be especially burdened, the legislation violated section 504 of the Rehabilitation Act of 1973, which bars discrimination in the distribution of Federal benefits. While the Court took seriously the adverse unpact on these citizens, Justice Marshall's majority opinion nevertheless stated that the benefit provided through the program is not "adequate hcalth care" tailored to individual needs, but, rather, a "particular package of health care services." Id. at 303. States have considerable discretion to determine and to alter the amount, scope, and duration of services they will provide. Id. at 307.

106. See Blumstein, supra note 40 , at 381-82 (violation of equal protection due to disparate impact would not be found without proof of discrininatory intent, citing Washington v. Davis, 426 U.S. 229 (1976) and Personnel Administrator v. Feeney, 442 U.S. 256 (1979)).

107. Goldberg v. Kelly, 397 U.S. 254, 268 \& n.8 (1970) (AFDC benefits are statutory entitlements akin to property interests); see also Blumstein, supra note 40, at 367 . 
the way in which the new program has classified them. Due process requirements do not govern the substantive decision to change the pohicy. ${ }^{108}$

As with tort reform, the equal protection implications of our jurisprudential inquiry differ significantly from those arising froin rationing statutes. The focus of this inquiry is not on exphicit, government-produced allocation scheines, but on resource decisions made by physicians and other providers in response to economic pressure from many sources, the government being but one. Thus, the relevant "state action" is not the direct legislative decision to reduce or alter Medicare and Medicaid benefits. Rather, it might appear in either of two forms: (1) as a judicial decision to admit econormic evidence at trial or to instruct a jury that they may consider such evidence as possibly mitigating a defendant-physician's liability; ${ }^{109}$ or (2) as an explicit legislative permission for medical standards of care to vary according to economic exigencies. Sucl legislation is not likely to appear in the foreseeable future, however. Explicitly reducing indigent citizens' access to tort remedies would be, at the least, a inatter of some political delicacy. Common law jurists can soinetimes address such difficult social issues more adroitly and more forcefully thian can elected representatives, ${ }^{110}$ at least partly because of the sheer size of legislative bodies. Thus, if state action is to be found at all, it would more likely appear througli the judicial than the legislative branch, as case law rather tlian as statute.

In suin, existing equal protection literature and the litigation produced by tort reform and the rationing of liealth care resources cannot directly confirm whether it would offend equal protection to permit pliysicians to deliver a lower standard of care to the poor. Some guidelines, however, einerge from the discussion.

108. Blumstein, supra note 40 , at $372-75$.

109. Cf. Shelley v. Kraemer, 334 U.S. 1 (1948) (judicial enforcement im equity of racially restrictive covenant to bar sale of property by white seller to black buyer is state action in violation of fourteenth amendment equal protection guarantee); Barrows v. Jackson, 346 U.S. 249 (1953) (state action rule of Shelley v. Kraemer apphies in actions for damages).

110. Consider, for example, the rather restrictive character of California's Natural Death Act. CAL. HEALTH \& SAFETY CODE $\$ \S 7185-7195$. It is binding only for persons who have been diagnosed as terminally ill, and it requires a cumbersome 14-day wait before implementation. See id. $\S 7188$. In contrast, recent Califorma deeisions exphicitly permit life-support to be withheld under broader conditions. See Bouvia v. Superior Court, 179 Cal. App. 3d 1127, 225 Cal. Rptr. 297 (1986) (patient who was not diagnosed as terminally ill could choose to discontinue medical treatment); Bartling v. Superior Court, 163 Cal. App. 3d 186, 209 Cal Rptr. 220 (1984) (same); Barber v. Superior Court, 147 Cal. App. 3d 1006, 195 Cal. Rptr. 484 (1983) (doctor's disconnection of life support was not homocide even though patient had not exeeuted a written directive pursuant to the Natural Death Act). 


\section{Standards of Care}

As noted in the tort reform cases, the right to seek full redress for one's injuries is not a "fundamental right," nor is a "suspect classification" employed. Socioeconomic variations in the inedical standard of care would not constitute exphicit discrimination on the basis of race or any other suspect category. Although the poor would be most adversely affected, such differential impact is not intrinsically proscribed. While the state may not burden a person's exercise of fundamental rights on the basis of wealth, ${ }^{111}$ the Supreme Court does not regard classifications that burden the poor as suspect in and of theinselves. "Wealth classifications" therefore receive only rational basis scrutiny. ${ }^{112}$

Since neither a fundamental right nor a suspect classification is involved, courts probably wonld not imvoke strict scrutiny to consider whether the standard of care may permissibly be shifted downward for patients with lesser financial resources. To apply either the "rational basis" or the "intermediate" test, a court would need to balance interests. ${ }^{13}$ The court would first identify and evaluate the state's interest. (Is it "important" -or merely "legitinate"?) It would then assess the relationship between that interest and the classification-that is, the basis on which medical care is denied to soine people. (Is there only a "rational" relationship, or is it "substantial"?) In the end, the process would involve weighing the individual's interest in medical care and in access to a legal remedy agaimst society's imterest in limiting health care expenditures.

Unfortunately, to conclude that courts would have to engage in this balancing does not help us to resolve our problein-it only restates it. Our very purpose is to determine a ineans of balancing physicians' fiduciary obligations to their patients with their newer responsibilities to help society contain costs. If we must find that balance before we can answer the equal protection question, then we can hardly appeal to the equal protection clause to answer our jurisprudential query. This legal concept, like the preceding ones, fails to resolve the dilenıma.

111. Shapiro v. Thompson, 394 U.S. 618 (1969) (voiding one-year waiting period for new residents to receive welfare benefits); Harper v. Virginia Bd. of Elections, 383 U.S. 663 (1966) (striking poll tax); Gideon v. Wainwright, 372 U.S. 335 (1963) (mandating appointment of counsel for indigent criminal defendants).

112. San Antonio Indep. School Dist. v. Rodriguez, 411 U.S. 1 (1973).

113. The element of "balancing" involved in the "intermediate" test has becn recognized by commentators and courts. See Carson v. Maurer, 120 N.H. 925, 933, 424 A.2d 825, 831 (1980); J. NowaK, R. Rotunda \& J. Young, supra note 85, at 533-34 \& n.26; cf. Blumstein, supra note 40, at 369 (discussing ad hoc balancing test applied to asserted duc process violations). Even the deferential "rational basis" test, however, requires an assessment of the nature of competing interests. Perhaps it should be described as weighing with a thumb on the scales. 


\section{F. Summary}

None of the legal rules and concepts we have examined is equipped to resolve the rather novel situation that we face: the necessity for physicians to provide less-than-standard health care where financial resources are especially scarce. We have seen that none of the methods by which the courts identify the standard of care can accommodate nonmedical, third party financial considerations. The judicial approval granted to shifts in custom and to respectable minorities does not extend to reductions in the level of care. And the locality rule, which does permit standards to be adjusted by regional resources, cannot adapt to the wide variations of resources within a locality. Neither is the dilemma resolved by requiring physicians to inform patients fully about all the desirable health care interventions they will not be receiving, for this may represent a serious assault on the fiduciary relationship. Finally, we cannot determine whether indigent patients' lesser access to a legal remedy for their medical mjuries is a violation of equal protection until we resolve the very issue for which we seek legal guidance: how to find a suitable balance between physicians' traditional fiduciary obligations to patients and their new econonric responsibilities.

\section{III \\ Possible Resolutions}

A new approach is needed. Although the aim of this Article is more to explore the problem than to resolve it, I hope at least to suggest a new direction for search. After considering and rejecting several options, I will turn to what is perhaps the most fundamental concept of tort law: reasonableness.

\section{A. Retain Current Standards of Care}

One approach is to insist that current standards of care and rules of liability remain intact. Physicians might sometnnes be treated unfairly, it may be argued, but this alone does not warrant change. The law is an imperfect instrument of justice, and occasional unfairness is inevitable. In this case, openly permitting physicians to reduce quality of care for the poor inay imvite physicians to be less than diligent in their efforts to maintain quality of care, and to give in too easily to economic pressures. This approach insists that only by mamtaining tort liability can we adequately protect the important physician-patient fiduciary relationship. ${ }^{114}$

This view seems to have influenced recent congressional action. Section 9403 of the Consolidated Omnibus Reconciliation Act of 1985

114. A position similar to this is presented in Furrow, Medical Malpractice and Cost Containment: Tightening the Screws, 36 CASE W. RES. L. REv. 985 (1986). 
(COBRA $)^{115}$ denies Medicare reimbursement not only where health care has been excessive or mappropriate (as has always been the case), but also where care has been madequate or substandard. Where such action is taken, the Peer Review Organization responsible for the decision must also send a letter to the patient explaining the nature and grounds for the payment denial. ${ }^{16}$ Arising as it does on the heels of complaints that Medicare's DRG prospective reimbursement system is leading to a poorer quality of care, this new provision is plainly designed to pressure physicians, hospitals, and other providers to resist the temptation to reduce their medical standards in response to economic constraints.

The chief inerit of retaining current standards is the strong emphasis upon the fiduciary relationship. Cost containment has advocates aplenty; if the patient cannot count on the support of his own physician, he may have no one to protect his interests. Further, there are still many ways in which physicians can reduce the quantity and cost of care without impairing quality. It is morally and legally imperative that physicians persist in their search for such solutions. ${ }^{117}$

Yet there are limits. Where scarcity of resources is quite severethe very cases in which we are inost interested-not even the threat of hability can induce physicians to do the impossible. Faced with the prospect of unremitting liability for inadequacies of care over which they have no control, physicians nuay simply opt not to care for the poor at all. So long as they are free to choose with whoin they will contract to dehver their services, physicians are legally entitled to ignore the poor altogether. ${ }^{118}$ If providing good quality health care for the poor is our goal, this surely would be the worst outcome of all. A liability rule that leads to this result is unacceptable.

\section{B. Liability Shared with Hospital or with Third Party Payers}

A second approach would maintain the medical standard of care, but would alleviate the physician's legal burden by extending liability to third parties. This approach has two variations, distinguished by the identity of the third party to whom hability would attach.

In one variation, hospitals would bear direct liability where their economic pressures on physicians have prompted inferior care. Hospitals, after all, are intimately involved in cost containment. For example, Medicare's DRG reimbursement system currently applies only to hospi-

115. Act of Apr. 7, 1986, Pub. L. No. 99-272, 1986 U.S. Code CoNG. \& ADMIN. NEws (100 Stat.) 200.

116. McIlrath, Medicare Rule May Add to Liability Woes, Am. Med. News, May 30, 1986, at 1, col. 1.

117. Angell, supra note 1, at 1207.

118. See Marsh, supra note 28 , at $160-61$ and cases cited therein; Note, supra note 27 , at 1017. 
tals, and not directly to physicians. Although hospitals can partly control their expenses through decisions about such things as construction, equipment purchases, and staffing levels, physicians nevertheless control some 60 to $80 \%$ of spending through their decisions concerning whom to admit, for how long, and what products and services to prescribe. Thus, hospitals must actively sohicit the cooperation of physicians in cost containment, whether through the "carrots" of financial reward for successful resource conservation, or the "sticks" of threatened penalties for excessive consumption. ${ }^{119}$

If hospitals are a major source of the fiscal pressures placed upon physicians, then perhaps there should be a rebuttable presumption that, where insufficient care has led to medical mjury, hospitals should jointly share in physicians' hability. ${ }^{120}$ In order to limit its application to cases in which the hospital influenced the physician's decisions, "the existence of a utilization protocol or other cost-cutting initiative apphicable to the mjured patient would be prerequisite to mvoking the presumption."121 The hospital would then defend itself by demonstrating that the event was the product of ordinary neghigence, not of economic constraints.

This proposal has several strengths. First, where hospitals stand to be held presumptively hable for the results of overzealous budgetwatching, they inay be inore careful about miposing economic pressures on their staff physicians. Further, such mutual hability may encourage physicians and hospitals to work together to identify new protocols of care that are both medically and economically sound. The physician may know what the hospital charges for a given procedure, for example, but may not be aware of that procedure's actual cost to the hospital. ${ }^{122}$ Mutual cooperation will be essential if patients and accountants abike are to be satisfied.

Unfortunately, this promising suggestion is madequate to meet the more difficult cases in which we are especially interested. While more efficient use of resources is obviously desirable, physicians and hospitals under the direst scarcity may still be unable to dehiver the level of care that is generally available elsewhere. Where this is true, continued tort

119. Egdahl \& Taft, supra note 23, at 59; Hershey, supra note 23, at $61-62$ (role of fourth-party audit organizations in utilization review and control programs); see text accompanying notes 1-38.

120. This position is advocated in Note, supra note 27, at 1019-22; see also Curran, A Further Solution to Malpractice Problem: Corporate Liability and Risk Management in Hospitals, 310 NEW ENG. J. MED. 704 (1984).

121. Note, supra note 27 , at 1020 . Such utilization controls might, for example, include limits on access to expensive technology, daily scrutiny of patients' charts with challenges to justify continued hospitalization or to defend a particular regimen of care, or streamlined guidelines for use of various diagnostic tests.

122. Finkler, The Distinction Between Cost and Charges, 96 Annals INTERNal Med. 102 (1982) (charges may not reflect actual costs). 
pressures will not constitute an incentive to meet customary standards, but a penalty for failure to do the impossible.

Furthermore, to add the hospital as a defendant will aid the physician little, once an episode of substandard care actually results in a lawsuit. Regardless of the pressures upon him to conserve resources, the physician must ordmarily retain final decision power regarding what particular interventions to offer his patient. Hospital administrators must not dictate the daily details of care. Therefore, the physician must bear responsibihity for those decisions, legally as well as morally. He may be consoled by the presence of others in the defendants' box, and his insurance company's financial burden may be eased as the costs of adverse judgments are spread ainong inore payers. But his liability is not necessarily lessened, nor are the trouble and trauma of enduring the lawsuit.

In the final analysis, a presumption of jomt physician-hospital liability for substandard care may encourage physicians and hospitals to collaborate in maintaining quality of care, ${ }^{123}$ and it might even reduce physicians' hability insurance premiums. It will not, however, help physicians to avoid unfair hability im situations where substandard care cannot be averted.

A second variant of this shared hability approach would encompass third party payers and their cost-containment prograins. This approach was exphicitly embraced, in dicta, by the Califorma Court of Appeal in Wickline v. State of California. ${ }^{124}$ The case concerned Lois Wickline, an mdigent patient who suffered from vascular complications following bilateral aorto-femoral bypass surgery for Leriche's syndrome. Her physicians behieved that eight more hospital days should be added to the ten already approved by Medi-Cal. However, when Medi-Cal utilization officials approved just four extra days, Mrs. Wickline's physicians, reluctantly but without protest, discharged her after ouly the four extra days. Within a few weeks after discharge, continuing complications necessitated ainputation of the patient's leg.

Mrs. Wickline sued ouly the state of California, declining to sue her physicians, with whom she had had good rapport. ${ }^{125}$ Though she was

123. Or it could aggravate antagonisms. See Note, supra note 27, at 1021.

124. 192 Cal. App. 3d 1630, 228 Cal. Rptr. 661 (1986), review granted 231 Cal.Rptr. 560, 727 P.2d 753 (1986), review dismissed, 239 Cal. Rptr. 805, 741 P.2d 613 (1987) (originally published at 183 Cal. App. 3d 1175 (1986)). Though Wickline was the first case to directly consider the malpractice implications of cost containment, a second case has recently appeared. A gag order has made details difficult to obtain, but the case involves an HMO subscriber who alleges that her cancer would have been detected earlier but for the HMO's regulations and financial incentives for constraining the level of care. See Meyer, Suit Blames HMO Capitation for Damaging Quality of Care, Am. Med. News, Sept. 4, 1987, at 2, 46.

125. Carlova, A Jury Lands a \$500,000 Haymaker on Health Bureaucrats, MED. EcoN., May 16,1983 , at 80 . 
awarded $\$ 500,000$ at trial, the verdict was overturned on appeal. ${ }^{126}$ According to the appellate court, the physicians' failure to protest MediCal's decision meant that they, not the payer, were causally more responsible for whatever mjuries may have resulted from the early discharge.

While declining to find neghigence in this case, however, the court's dicta opened the door wide to third party payers' sharing legal responsibility for the medical effects of their cost-containment pohicies. A patient deprived of adequate care is entitled to recover "from all those responsible for the deprivation of such care, including, when appropriate, health care payors. Third party payors of health care services can be held legally accountable when medically inappropriate decisions result from defects in the design or implementation of cost contamment mechanisms." 127

Nevertheless, the court emphasized that this shared liability does not relieve physicians of their obligation to ensure that their patients receive proper care. Mrs. Wickline's physicians could have-and should have-protested the demial of extra hospital days by contacting Medi-Cal utilization authorities. The physician is ultimately responsible for medical decisions, and although Mrs. Wickline's physicians may have been intimidated by the agency's actions, they were neither paralyzed nor powerless to act on the patient's behalf. ${ }^{128}$ "While we recognize, realistically, that cost consciousness has become a permanent feature of the health care system, it is essential that cost linitation programs not be permitted to corrupt inedical judgnient." 129

Paradoxically, the court's erroneous view of the relationship between third party payers and medical decisions could lead to a more lenient standard of hability than physicians would bear under a more accurate view of this relationship. Although the court acknowledged that physicians bear ultimate responsibility to make patient care decisions, ${ }^{130}$ overall its opimion reflects a view that third party payers have the capacity not only to place economic pressures directly upon physicians but also, indeed, to exert direct control over such decisions as length of hospitalization. Thus, the court stated that Medi-Cal authorizes length of stay, ${ }^{131}$ that defective cost-containment mechamisms can cause personal injuries, ${ }^{132}$ and that physicians can choose whether to comply with these third party decisions or to protest. ${ }^{133}$

\footnotetext{
126. Wickline, 192 Cal. App. 3d at 1632, 228 Cal. Rptr. at 661.

127. Id. at 1645, $228 \mathrm{Cal}$. Rptr. at 670-71.

128. Id.

129. Id. at $1647,228 \mathrm{Cal}$. Rptr. at 672.

130. Id. at 1644-45, $228 \mathrm{Cal} \mathrm{Rptr.} \mathrm{at} 663$.

131. Id. at 1638-39, $228 \mathrm{Cal} \mathrm{Rptr.} \mathrm{at} 667$.

132. Id. at $1634,1645,228 \mathrm{Cal} \mathrm{Rptr}$ at $663,671$.

133. Id. at $1638-39,1645,228$ Cal Rptr. at 667,671 .
} 
In fact, neither Medi-Cal nor any other third party payer can authorize or deny length of stay or any other treatment. They authorize amounts of payment. And physicians do not actually comply with these decisions about payment, for they have no control over the amount of money that a payer gives to the hospital. Further, these payment decisions do not even directly pressure physicians' decisions. It is the hospital, not the physician, who will be short changed if patients consume more hospital resources than the third party reimbursement will cover. The hospital can, of course, place its own pressures directly on the physicians. Many hospitals must do so, as we have seen, ${ }^{134}$ particularly if they care for large numbers of indigent patients. Nevertheless, the pressures from third party payers upon physicians are indirect.

By erroneously presuming that third party payers have such a large and direct role in making medical decisions, the Wickline court actually underestimated physicians' responsibilities. Apparently assuming that reimbursement decisions can hiterally dictate health care decisions, the court defined the physician's responsibilities largely in terms of obligations to petition and protest the payers' decisions. In fact, since physicians alone have the clinical authority and the medical responsibility to admit, treat, and discharge, the court could have taken the inuch stronger position that physicians are obliged to ignore third party reimbursement decisions that might adversely affect patient care. Their protest, after all, does not benefit the current patient at all. It benefits the hospital and future patients by augmenting the hospital's resources to care for indigent patients.

In sum, the court miputed to third party payers a direct causal role they do not possess. A different view of the causality issue could thus lead to very different conclusions concerning potential tort liability. Because they bear final responsibility to make medical decisions, physicians could in principle bear sole or primary responsibility for inadequate care. Given this principle, the real question is how much personal pressure and economic sanctions physicians are obligated to endure from their hospitals, to fulfill their duty to secure the best care for each patient.

This last issue is a variant of our current inquiry, as we ask how strenuously physicians are obliged to resist financial pressures-and at what price, both personally and legally. As above, however, extending liability to those who exert pressures does not necessarily relieve physicians of their predicament.

\section{Peer Review and Minimum Standards}

The federal government has attempted a third approach to the prob-

134. See supra text accompanying notes $119-23$. 
lem of reconciling cost containment with standards of care, in two renditions. In response to rising health care costs and a perceived overutilization of medical services, Congress in 1972 estabhished Professional Standards Review Organizations (PSRO's) ${ }^{135}$ to oversee both the quality and quantity of care provided to recipients of federal health insurance (Medicare, Medicaid, and maternal and child health prograins). Toward that end, PSRO's were required to develop explicit norms of care for various health conditions, focusing particularly on lengths of hospital stay and on the use of expensive technologies. These were to represent a cost-conscious basic minimum of care that should then be delivered to all patients. Physicians who complied with these norms were granted immunity from civil liability, ${ }^{136}$ thereby preempting common law remedies. This immunity was intended to encourage them to abandon expensive practices of defensive medicine.

Although PSRO's no longer exist, their key elements have been incorporated into more recent legislation. Peer Review Orgamizations (PRO's), created in 1982 by the Tax Equity and Fiscal Responsibility Act (TEFRA), ${ }^{137}$ are designated to oversee the quality, necessity, appropriateness, and cost effectiveness of care delivered to Medicare patients. Although PRO's were not initially cliarged with creating specific guidelines of care, in 1986 they were assigned the task of denying payment for substandard or inadequate care. ${ }^{138}$ This function will require PRO's to develop criteria to guide these decisions. Physicians who practice in accordance with such PRO standards are granted immunity from civil liability, as they were under the PSRO's. ${ }^{139}$

In theory at least, this approacli has advantages. If pliysicians can agree on more econonical ways to deliver quality care, and if they can be induced to give up the expensive, often useless, and sometimes harmful practices of defensive medicine, then patients and payers alike will benefit. If civil immunity provisions reduce nedical malpractice insurance costs, medical care itself slould be less expensive and therefore more widely available.

Such standardized minimun criteria will not work in practice lowever. First, such gnidehines of care could not possibly be sufficiently precise, accurate, up-to-date, and patient-specific to dictate the daily details of medical care. With this point we are already familiar.

135. 42 U.S.C. $\$ 1320$ c (Supp. II 1972) (ameuded 1982).

136. 42 U.S.C. \$ 1320c-16(c) (Supp. II 1972) (omitted by 1982 amendments, see infra note 139 and accompanying text).

137. Pub. L. No. $97-248, \S 1151,96$ Stat. 324, 382 (1982). The Act also established DRG prospective payment for Medicare.

138. Comprehensive Omnibus Budget Reconciliation Act (COBRA), Pub. L. No. 99-272, $\S 9403(a)(2), 100$ Stat. 82, 200 (1986). See supra text accompanying note 115.

139. 42 U.S.C. $\S 1320 c-6(c)(1982)$. 
Second, the civil immunity granted is mostly illusory. Recognizing the inappropriateness of "cookbook" medicine, the old PSRO and new PRO regulations require that physicians continue to exercise "due care." 140 Without such a requirement, patients would have virtually no civil protection against medical incoinpetence or carelessness, since physicians and review organizations would be free to endorse virtually any standard of care they wished. However, adding this "due care" requirement essentially reinstates the common law standards of liability, because the physician who adheres to the relevant formalized norm could still be found liable if the patient needed niore elaborate care. ${ }^{141}$

Finally, so long as we face stratified scarcity, there is no satisfactory way in which to choose a single "basic minimum" standard to which all physicians must adhere. If we simply asseinble a statistical sunnnary of prevailing practices-as many PSRO's did-we will only reify the inflated customs that we hope to trim. ${ }^{142}$ Further, physicians who attend the poor may not be able to meet these standards. Unwilling to risk suits for their failure to meet such high standards, these physicians may choose to withdraw their services, creating a greater scarcity of inedical care for the poor. On the other hand, it is no more desirable to seek the "lowest common denommator," requiring for all patients only the bare minimum standard that is provided under the niost destitute circuinstances. Quality of care, and recourse for civil restitution, could decline dramatically. So long as resources are niarkedly unequal, we cannot reasonably expect to develop a single, explicitly codified standard of care to which all physicians may fairly be held.

\section{Private Contracting and Exculpatory Clauses}

Whereas the preceding proposals maintam traditional standards of care and tort rules of liabihity, a fourth approach would open tlose standards and rules to private negotiation. Such negotiation is not currently an option. Though initiation of a physician-patient relationslip is of course contractual, courts have been exceedingly reluctant to permit bargaiming over the standard of care withm that relationship. Courts and commentators have pointed out that patients are generally in a poor bargaining position. They further argue that reducing professional standards is both contrary to public policy and inappropriate for a

140. 42 U.S.C. $\$ 1320 c-6(c)(2)$ (1982).

141. For discussions of the immunity provisions' effect on civil liability, see Note, PSRO: Malpractice Liability and the Impact of the Civil Immunity Clause, 62 GEO. L.J. 1499, 1506 (1974); Note, supra note 33, at 935. Because its problems were well explored in discussions of PSRO's, the immunity provision built into the PRO legislation has received little attention.

142. Note, supra note 33, at 935; Note, Federally Imposed Self-Regulation of Medical Practice, 42 Geo. WASH. L. REV. 822, 843 (1974). 
responsible and learned profession. ${ }^{143}$

However, recent commentators are beginning to question this stance. ${ }^{144}$ They assert that individuals know their own risk preferences far better than do legislators, courts, or regulators, and that individuals can better determine what they are willing to pay to cover the risks of negligent iatrogenesis.

Through private contracting, patients could agree to any of a variety of alternate hability arrangeinents, in exchange for lower fees or insurance premiums. At one extreine, a patient might accept inedical care as is, by agreeing to an exculpatory clause that shifts all risks to the patient (with the possible exception of gross neghigence or willful harm). ${ }^{145}$ At the other extreme, patient and provider might agree to a no-fault arrangeinent in which the physician shoulders all burdens of compensation.

In between he inany variants of traditional tort liability. One might alter the rules of physician liability by considering the patient's contributory fault. Or negotiators could alter damages rules, such as limiting the size of recovery or the types of damages for which recovery will be allowed. Thus, damages for pain and suffering might be excluded. Similarly, the inedical standard of care could itself be opened to negotiation, as where consumers might arrange with HMO providers to accept more economical approaches to diagnosis and therapy. Finally, the parties could contract for specific dispute resolution procedures such as arbitration. $^{146}$

According to the advocates of private contracting, courts' traditional reluctance to accept such agreements represents an unwarranted intrusion into citizens' freedom to contract. ${ }^{147}$ They also argne that the ban on private contractimg impedes the improveinent of fiscal efficiency in health care dehvery. ${ }^{148}$

143. See, e.g., Tunkl v. Regents of Univ. of Cal., 60 Cal. 2d 92, 383 P.2d 441, 32 Cal. Rptr. 33 (1963) (liability release form as condition for admission to charitable hospital is invalid as against public policy); Ginsburg, Kahn, Thornhill \& Gambardella, Contractual Revisions to Medical Malpractice Liability, LAw \& CONTEMP. PROBS., Spring 1986, at 253, 253-55 [hereinafter Ginsburg].

144. E.g., P. Danzon, Medical Malpractice: Theory, Evidence, and Public Policy 209 (1985); Epstein, Medical Malpractice: Its Cause and Cure, in THE Economics OF MEDICAL MALPRACTICE 245 (S. Rottenburg ed. 1978); Robinson, supra note 29, at 174, 183-99.

145. For arguments im favor of such exculpatory clauses, see P. DANzon, supra note 144, at 209; Epstein, supra note 29, at 256-57; Robinson, supra note 144, at 183.

146. Epstein, Medical Malpractice, Imperfect Information, and the Contractual Foundation for Medical Services, LAW \& ConTEMP. ProBs., Spring 1986, at 201, 205-10; Havighurst, supra note 27, at 143, 161-62, 167; see also P. Danzon, supra note 144, at 208-13; Epstem, supra note 144, at 254-57; Havighurst, Reforming Malpractice Law Through Consumer Choice, 3 HEALTH AfF. 63, 6869 (1984).

147. Epstein, supra note 144, at 254-55.

148. P. Danzon, supra note 144, at 212; Havighurst, supra note 146, at 161-62. 
Such contracting has acknowledged hazards, however. In order to construct contracts that truly reflect their preferences, consumers must be well informed. ${ }^{149}$ They would need to know, for example, the probability of each sort of injury and the corresponding compensation that each proposed contract plan would provide. Such information, however, could be difficult to obtain. If contracts exempt the physician from liability for failure to obtain patients' informed consent (the situation in "as is" contracting), then the physician would have little incentive to ensure that prospective patients have the very sort of information they most need for informed contracting. ${ }^{150}$

Further, maintaining and mointoring the quality of care could be difficult where physicians are contractually exempt from hability for lowquality care. While licensing boards and lospital oversight committees can eliminate the worst offenders, patients may not be able to assure the quality of their care once they give up the right to sue for negligence. Indeed, the very concept of malpractice-substandard care-could evaporate if each provider were allowed to define his own standard of care. ${ }^{151}$

Defenders of contracting may argue, however, that the dangers of mdividual contracting are diminished where consumers and providers contract with each other as groups ratlier than as individuals. For example, if employers and labor representatives negotiate with HMO officials, then competition ainong providers to secure such lucrative contracts may proinpt them not only to maintain a high quality of care, but also to provide consumer-negotiators with sufficient information necessary for effective contracting. ${ }^{152}$

In the end, whether or not we can successfully defend private contracting or exculpatory arrangements where consumers (individually or in groups) have political and economic power, we again encounter probleins regarding those citizens who have neither money nor power. The very concept of contracting presupposes freedom of choice, yet this is the very element that indigent contractors substantially lack. ${ }^{153}$

First, they may have a much smaller array of providers with whoin to negotiate. In a system such as California's prudent buyer plan, for example, Medi-Cal patients must obtain their care exclusively froin

149. Robinson, supra note 29, at 188-93; Epstein, supra note 146, at 201-05.

150. P. Danzon, supra note 144, at 210, 212.

151. Id. at $210,212,222$.

152. Id. at 211; Epstein, supra note 146, at 210; French, Commentary, in THE Economics or Medical MALPRACTICE 286-87 (S. Rottenberg ed. 1978); Fine \& Sunshine, supra note 10, at 217 21.

153. For discussions of freedoin of ehoice in health care and how parties' relative size and vulnerability may affect such freedom, see Ginsburg, supra note 143, at 255; Robinson, supra note 29 , at 198. 
approved providers. ${ }^{154}$ Even without such formal constraints, choice may be limited. With fewer resources available for indigent patients, and as the decreasing quality of care increases their liability, many physicians may elect not to accept indigent patients at all.

The threat of such liability could prompt other physicians to offer their services only to those patients who would agree to waive their rights to a lawsuit. In other words, as the physician feels trapped between an economic inability to provide standard care and a legal inability to cite such resource scarcity as a defense, he may insist on a contract of complete exculpation as a precondition for rendering any medical care at all.

In return, the indigent patient would receive no quid pro quo. She would not reap the economic benefit of spending less on her health care, for she does not pay for it in the first place. The government pays for the care, and the government would tally the savings. The patient would then receive care of questionable quality, yet would have lost all recourse for injuries from negligence.

Whether or not courts can be persuaded to accept private contracts negotiated by parties of comparable bargaining power, it is highly doubtful that they would, or should, accept the virtually coerced results of such unequal contracting. ${ }^{155}$ Unable to secure care elsewhere, and lacking bargaining power, the indigent patient essentially would be con-

154. CAL. WELF. \& INST. CODE $§ 14086$ (West Supp. 1983) (limited exceptions for HMO's and state hospitals); see also Comment, supra note 50, at 459.

155. See, e.g., Tunkl v. Regents of Univ. of Cal., 60 Cal. 2d 92, 102, 383 P.2d 441, 447, 32 Cal. Rptr. 33, 39 (1963) (hospital's release from liability as condition of admission held invalid). Havighurst notes that courts are hesitant to uphold contractual reallocations of risk where bargaining power is unequal, or where one party does not have readily available alternatives. He does not, however, agree with the conclusion offered here, that these two factors should effectively preclude private liability contracting in the medical care of the indigent. Havighurst, supra note 27, at 165-68; see also Robinson, supra note 29, at 198.

A rather different form of private contracting ought at least to be mentioned. Jeffrey O'Connell suggests, as one of his "neo-no-fault" proposals, that providers should purchase insurance policies that would reimburse patients, regardless of fault, for economic losses due to specified injuries. The provider would obligate himself automatically to tender payment to patients suffering a covered injury within 90 days. The patient would similarly have a limited time in which either to accept the offer and thereby waive all rights to sue, or to decline it and pursue a tort remedy. O'Connell, NeoNo-Fault Remedies for Medical Injuries: Coordinated Statutory and Contractual Alternatives, LAw \& CONTEMP. ProBs., Spring 1986, at 125, 131-34.

Again, while this proposal might be promising for "mainstream medicine," there may still be problems regarding the indigent. The insurance companies that fund such plans may be reluctant to enter into arrangements with physicians and hospitals who care primarily for the indigent, if these providers' lesser economic resources lead to documentably higher rates of morbidity and mortality, as is sometimes the case. See Greater Wash. D.C. Area Council of Senior Citizens v. District of Columbia Gov't, 406 F. Supp. 768 (D.D.C. 1975); Boone v. Tate, 4 Pa. Commw. 101, 286 A.2d 26 (1972). Further, where the indigent patient declines a tender of payment in favor of pursuing a tort remedy, all of the problems with which we are now well acquainted may arise. The physician may be held legally liable for an unavoidably diminished quality of care. 
fronted with an adhesion contract. ${ }^{156}$ Quite likely, courts would consider such unreasonable favoritism toward providers to be unconscionable. ${ }^{157}$

\section{E. Resource Based Reference Groups}

Whereas the previous approach shifts the standard of care indirectly as the rules of liability are contractually altered, an alternative approach would base the standard of care directly upon the resources available to the health care provider. The applicable standard of care for each individual provider would be determined by reference to other providers in similar economic circumstances, rather than by reference to other providers in the same geographic area. Thus, it has been suggested that physicians practicing in HMO's should be judged, not according to the overly expensive customs of hospital medicine generally, but instead according to the practices prevailing in other HMO's. ${ }^{158}$ Sinnilarly, we could judge Medi-Cal care by reference to other Medi-Cal providers. ${ }^{159}$

The chief advantage of this approach is that, by judging care according to broad reference groups, inalpractice law would retain its traditional deference to professional custom. The provider's economic resources, rather than a geographic location, would define such custom. Defining malpractice according to economic conditions would avoid the primary problem encountered in private contracting, where each practitioner sets his own standards.

However, this approach could encourage seriously inadequate quality of care. To permit economically pressed physicians to be judged only against the practices of other similarly pressed physicians may invite them to debiver needlessly inferior care, safe in the knowledge that so long as the others in the reference group do likewise, all will have legal sanctuary.

Further, it may be very difficult to select the appropriate reference group. As Bovbjerg notes, HMO's may function in widely differing conditions. ${ }^{160}$ Similarly, using facilities such as public hospitals as one's reference group could create inappropriate comparisons between destitute inner-city hospitals and more affluent public community hospitals. In the end, there really are no tidy, preexisting categories froin which we

156. Cf. Restatement (SECOND) OF CONTRACTS $\$ 208$ comment d:

[G]ross inequality of bargaining power, together with terms unreasonably favorable to the stronger party, may confirm indications that the transaction involved elements of deception or compulsion, or may show that the weaker party had no meaningful choice, no real alternative, or did not in fact assent or appear to assent to the unfair terms.

157. Cf. Leff, Unconscionability and the Code-The Emperor's New Clause, 115 U. PA. L. REv. 485 (1967) (analyzing "procedural unconscionability" under UCC § 2-302).

158. Bovbjerg, supra note 50, at 1408-14.

159. See Comment, supra note 50, at $466-67$ (discussing but not endorsing this proposal).

160. Bovbjerg, supra note 50, at 1413-14. In the end, however, Bovbjerg supports the development of separate HMO malpractice standards. 
can identify appropriate reference groups. ${ }^{161}$ Defendants in a malpractice suit would need to identify and defend their choice of reference group before they could describe the practices prevailing in that group. Plaintiffs, who bear the initial responsibility to demonstrate the appropriate standards, would of course have to do likewise. As each side thus argues about the appropriate economic standard, they are no longer appealing to prevailing standards of a given reference group so much as offering an econounic argument about whether the level of care received by the patient was justified given the existing econoinic constraints.

\section{F. Rebuttable Presumption for Unitary Standard}

Let us then consider a direct econoinic defense, which would most plausibly take the form of a rebuttable presumption. Here, we would presume (as the law already does) that physicians owe all patients the same basic quality of care, regardless of their financial resources. ${ }^{162}$ Such a presumption is iniportant, for it is appropriate that the law urge physicians to seek the highest possible quality of care, and not to defer too easily to apparent constraints. A major purpose of tort law is, after all, the deterrence of needlessly injurious conduct.

However-and this is the novel element of the proposal-the law should offer econounically pressed physicians some opportunity to rebut this presuniption where their diminution of care arose by necessity and not by neghigence. But what sort of opportunity? The proposal raises a question nearly as large as that which it purports to answer. Several considerations seem relevant.

First, the physician's burden must be a heavy one. It must not suffice merely to balance his own patients' interests against others', for the physician's fiduciary commitment is to his patient, not to the hospital or to the public at large. A siniple balancing would quickly erode the presumption of a umitary standard of care.

The physician should also be required specifically to demonstrate the nature and severity of his fiscal constraints. This could include, for example, providing information about the hospital's overall economic situation, its uncompensated care burden, the needs of the plaintiff-patient compared with other patients' needs at the time, the pohicies developed within the hospital and elsewhere to cope with fiscal linits, and perhaps even the pressures that have been personally apphed to the physiciandefendant. In some instances hospitals inight be reluctant to supply such

161. A possible exception might be Veterans' Administration hospitals.

162. This requirement does not mean that we must forever retain the elaborate level of care many physicians currently provide. Physicians can and should eliminate useless and highly marginal interventions. Nevertheless, such trimmed standards should then represent the basic commitment the physician owes to all his patients, rich and poor. 
data, particularly where the hospital is a defendant with interests that diverge from the physician's. Thus, some new rules of discovery might be needed, along with more detailed legal specification of the physician's burdens of evidence and persuasion.

The physician should further demonstrate that alternatives to the substandard care were not readily available. Note that this element is hazardous. We must not require the physician to show that he exploited every conceivable opportumity, or attempted to "evade" the hospital's guidelines on behalf of the individual patient. To demand this would be to ignore the important point introduced above in Part I: the physician is mescapably a key agent of resource allocation. ${ }^{163}$ Scarce resources mean that for every patient who receives something, some other patient must do without. If the law required the physician to treat each patient as an exception to the otherwise apphicable cost guidelmes, it would in effect demand that he systematically iguore costs.

Rather than expecting the physician to show that he did his utmost for the imdividual patient, then, it might be preferable to require him to justify the general allocation principles that guided his decision, and the appropriateness of applying those principles to this patient. Thus, a hospital might issue criteria concerning which patients with infections should receive the most powerful, expensive antibiotics. If these guidelines can be justified as adequate medical practice in the face of serious economic constraints, they should be accepted. It would then be necessary to show that the patient's own infection met these guidelines, and that no serious clinical evidence warranted an exception.

While this rebuttable presumption approach is somewhat novel in allowing an economic defense to malpractice, it nevertheless has strong roots in traditional American tort law. It incorporates fundamental tort concepts of fairness and reasonableness. Medical malpractice litigation generally falls within that broad area of tort law that requires a finding of fault for the ascription of liability. ${ }^{164}$ This requirement, in turn, is essentially founded upon the moral notion of fairness. On one hand, we believe it is unfair for an innocent victim to bear the costs of someone else's intentionally or carelessly harmful conduct. Conversely, we also believe that we should not ordinarily require someone to pay for unfortunate occurrences when he is not at fault. ${ }^{165}$

163. See supra text accompanying note 44 .

164. Fault has been a cornerstone of American tort law ever since Massachusetts Chief Justice Lemuel Shaw asked, in 1850, whether Mr. Kendall was at fault when he accidentally struck Mr. Brown while separating two fighting dogs. Brown v. Kendall, 60 Mass. (6 Cush.) 292 (1850); see G. WHITE, TORT LAW IN AMERICA 14-16 (1980); Williams, Abandoning Medical Malpractice, 5 J. LEGAL MED. 549, 554-63 (1984).

165. See generally ARISTOTLE, Nichomachean ETHics, Book V; Coleman, Moral Theories of Torts: Their Scope and Limits, 1 LAW AND PHILOsophy 371, 373 (1982); Harper \& James, 
To determine whether someone is at fault, we generally ask whether his conduct was reasonable. We do not expect citizens to avoid all risks of harm, ouly unreasonable or unnecessary risks. ${ }^{166}$ And to gauge these risks, we appeal to the concept of the "reasonable person"-or, in the case of medicine, to the reasonable and prudent physician.

Reasonableness is determined by weighing the seriousness and likelilood of the liarm we wish to avoid against the burdens or costs incurred to avoid such liarm. ${ }^{167}$ Where resources are constrained, medical care that may be reasonable under otlier circumstances becomes less reasonable. Here, the liarms and costs concern not only an individual patient, but also all other patients who have reasonable claims to the saine scarce resources. A resource provided to one patient may lielp him to regain his liealth and thus to avoid the harms of unnecessary illness. However, the costs include not ouly the patient's direct expenses, inconvenience, and discomfort, but also other patients' lost opportunities as they are denied resources from which they might otherwise lave benefitted. ${ }^{168}$

The general theme of reasonableness and fairness can be traced througli some important lines of existing malpractice law, denionstrating the coinpatibility of this proposed rebuttable presumption approach with traditional tort law. The locality rule, for exainple, is strongly rooted in the idea of fairness. In 1880, Small v. Howard ${ }^{169}$ leld that the rural physician with fewer opportunities of observation and practice calmot fairly be lield to the same high degree of art and skill possessed by more eninent physicians practicing in larger cities. From its origin through its more recent modification, ${ }^{170}$ the locality rule lias always been based upon a realistic appraisal of the himts under which pliysicians nuust practice and the ways in which these himits constrain the care we may reasonably expect them to provide.

This saine tradition of reasonableness and fairness lias also influenced modern courts faced with the problem of hinited liealtli care resources. In Boone v. Tate, ${ }^{171}$ for example, a Philadelplia trial court

Accidents, Fault and Social Insurance, in FREEDOM AND RESPONSIBILITY 267 (Morris ed. 1961); Keeton \& O'Connell, Why Shift Loss?, in PHILOSOPHY of LAw 389 (Feinberg \& Gross eds. 1975); Wasserstrom, Strict Liability in the Criminal Law, in FREEDOM AND RESPONSIBILITY 273 (Morris ed. 1961).

166. Coleman, supra note 165 , at 380.

167. See Judge Learned Hand's formula in Urited States v. Carroll Towing Co., 159 F.2d 169, 173 (2d Cir. 1947) (probability and gravity of injury weighed against burden of taking adequate precautions).

168. For further discussion of this point, and of the broader question whether the Hand formula should generally be given an economic interpretation, see Morreim, supra note 38, at 1052 \& n.39.

169. 128 Mass. 131, 136 (1880), discussed in Brune v. Belinkoff, 354 Mass. 102, 105, 235 N.E.2d 793, 796 (1968).

170. See supra text aecoinpanying notes 46-49.

171. No. 70 Civ. 713, ship op. at 299 (Phil. County Ct. C.P. Apr. 30, 1971), dismissed as moot, 4 Pa. Commw. 101, 286 A.2d 26 (1972). 
ruled that, although severe staff shortages had led to increased morbidity and mortality at Philadelphia General Hospital (the only health care facility available for many of the city's indigent), the city's projected budget deficit justified the city-wide hiring freeze that had exacerbated these problems. The Commonwealth appeals court dismissed plaintiff's appeal, simce it had become moot when the new fiscal year ended the hiring freeze. ${ }^{172}$ Nevertheless, the appellate court suggested that even assuming "that mdigent persons are legally and constitutionally entitled to minimally adequate general hospital care provided by the City, the extent of the City's duty would depend upon all the circumstances existing at a given time imcluding other similarly mandated public needs and the public means." ${ }^{173}$ Both the trial and appellate courts therefore emphasized that the city's duties to serve citizens' health needs are "not only a function of medical skills and technology but also the financial ability of the City to supply these needs." 174

In Jersey City Medical Center v. Halstead, ${ }^{175}$ a New Jersey Superior Court granted an injunction for removal of a patient who, though ready for discharge for six months, had not been taken hoine by her adult son. Noting the hospital's severe bed shortage and quoting the Lucy Webb Hayes case of 1967, ${ }^{176}$ the Halstead court stated that a hospital has "a moral duty to reserve its accommodations for persons who actually need medical and hospital care." 177

Admittedly, not all courts have agreed. For example, the government of Washington, D.C., and its principal public hospital, "D.C. General," have been sued on a number of occasions because of alleged madequacies of care. In Greater Washington D.C. Area Council of Senior Citizens v. District of Columbia Government, ${ }^{178}$ the district court agreed that patient care in eight specific hospital departments was seriously inadequate. The court ruled that the hospital had an obligation to provide care to indigent residents in accordance with the standards exercised by hospitals generally im the commumity. More specifically, it held that the failure to carry out this obligation because of budgetary or political constraints does not preclude the court from finding the hospital in breach of its obligation. ${ }^{179}$

172. Id.

173. $4 \mathrm{~Pa}$. Commw. at 102,286 A.2d at 27 .

174. No. 70 Civ. 713 , slip op. at $299,308$.

175. 169 N.J. Super. 22, 404 A.2d 44 (1979).

176. Lucy Webb Hayes Nat'1 Training School v. Geoghegan, 281 F. Supp. 116 (D.D.C. 1967).

177. 169 N.J. Super. at 24,404 A.2d at 45 . Recall also that states are not obligated to provide any particular set of health care services in the first place. Rather, they are free to offer and alter such assistance with considerable discretion. See supra text accompanying notes 102-06.

178. 406 F. Supp. 768 (D.D.C. 1975).

179. Id. at 770 . 
Not all cases directly concern money or expensive equipment. Hospitals under economic constraints may increasingly be forced to trim their leading budget item: labor costs. In Horton v. Niagara Falls Memorial Medical Center, ${ }^{180}$ a New York appellate court held that the hospital's staff shortage did not preclude the close supervision that might have averted a mentally disoriented patient's fall froin a second story wimdow. ${ }^{181}$

These and similar case ${ }^{182}$ do not, however, contradict the argument that serious resource constraints should, at some point, be perimitted as a defense to malpractice. In these cases, the courts took pains to point out that the respective hospitals were not making adequate use of the resources they did have, or that they did not demonstrate serious efforts to improve their quality of care. In Greater Washington, for exainple, the court found that "only feeble efforts" had been initiated to remedy inadequacies in various departments despite the hospital's awareness of these shortcomings. ${ }^{183}$ The court concluded that the hospital's minimal efforts to improve had not been successful. "Their excuse that the conditions are a product of fiscal constraints is unacceptable absent a clear demonstration that even within those constraints, timely and positive efforts have been launched by exacting, sensitive and demanding administrators. These ingredients appear to be lacking." 184

Similarly, the Horton court dwelled at length upon the actions that the hospital could have taken to protect the patient, even within existing staff limitations. ${ }^{185}$ Thus, their conclusion was not that staff shortages per se are not a defense, but rather that this particular hospital's staff hmits did not actually preclude adequate patient supervision.

Furthermore, with the exception of Horton, the cases studied here are not tort suits to recover dannages, but requests for injunctions to order improvements in care. Thus, the D.C. Circuit stated in Doe v. General Hospital of D.C. ${ }^{186}$ that even though "the city's or hospital's resources [may be] seriously overburdened," and even though "[t]he hospital may be unable to fulfill its obligations to provide medical care to indigents without affirmative action by the legislative or the executive branch," there is "no reason for the court to refrain from declaring that the obligation exists even though persons beyond the reach of the court

180. 51 A.D.2d 152, 380 N.Y.S.2d 116 (1976).

181. Id. at 156,380 N.Y.S. $2 d$ at 121.

182. E.g., Doe v. General Hosp., 434 F.2d 427 (D.C. Cir. 1970) (inadequate resources no defense to court order mandating additional abortion procedures).

183. 406 F. Supp. at 771-72.

184. Id. at 775 (emphasis added).

185. 51 A.D.2d at 156,380 N.Y.S.2d at 121.

186. 434 F.2d 427 (D.C. Cir. 1970). 
prevent its discharge."187 Thus, the court does not penalize; it prods. Had the plaintiffs sought damages, the courts might have taken the hospital's fiscal constraints into consideration.

In sum, these cases do not oppose invoking cost constraints as a malpractice defense. Instead, they focus upon the admitted importance of making the best possible use of available resources and of striving continually for improvement.

To allow inadequate resources to serve as a direct malpractice defense under this "rebuttable presumption" approach, then, is consistent with traditional tort concepts of fairness and reasonableness. But must we achieve fairness to physicians only by sacrificing the equally traditional and important fiduciary obligations that physicians owe to patients? After all, by permitting physicians to plead cost constraints as a defense, courts would be exphicitly allowing them to provide lesser quality care to the poor-a result we have criticized in some of the earlier approaches. If a central function of tort law is to deter undesirable conduct and thereby, at least in medicine, to serve as a system of quality control, ${ }^{188}$ then might not this approach undermine an important mission of malpractice law?

While we cannot entirely answer this difficult question satisfactorily, we can at least show that the rebuttable presumption approach honors fiduciary obligations better than the alternatives discussed above. Moreover, this approach can help direct us toward the forum in which resource questions must ultimately be answered: society as a whole.

First, this approach still presumes that physicians are legally obligated to deliver to all patients the same basic minimum of "ordinary and reasonable care," regardless of their financial resources. Any deviation from this standard must be carefully and specifically justified-not routinely accepted as part of the health care system, as in the "private contracting" and "resource based" standards discussed above.

Second, an adequate rebuttal to the presumption of standard care would require that the physician demonstrate not only that his resources are limited, but also that he and his institution are making good use of the resources they do have. After all, as cases like Greater Washington and Horton illustrate, we can hardly argue that resource limits constrained care when, in fact, better care could have been delivered even within those limits. This requirement, in turn, stands as an important incentive to physicians and hospitals to strive for the highest quality of care they can achieve. If sound management of available resources stands as a threshold requirement to mvoking the "resource defense,"

187. Id. at 433 .

188. P. DANzon, supra note 144, at 210, 221-22. 
providers should be powerfully motivated to keep their standards as high as possible. ${ }^{189}$

Where providers have made good use of existing resources, and where they are still constrained to provide substandard care, courts should then be willing to accept appropriate evidence to rebut the presumption of standard care. In allowing this, we are not conceding that substantial differences of care for rich and poor are morally acceptable, but only that we shall not hold the health care provider culpable for such discrepancies. ${ }^{190}$

\section{CONCLUSION}

So long as health care resources are stratified, with considerably fewer resources available to the poor, then the poor will come up short no matter how we answer our jurisprudential challenge. If we allow physicians to plead costs as a defense, we are explicitly conceding that the poor shall have lesser access to remedies for their malpractice injuries. But if we deny such a defense, then physicians may be reluctant to render their services to the poor at all.

Ultimately, resource allocation questions belong to society as a whole, and not specifically to its judiciary. With limited national resources, we must make difficult priority decisions that, even under the best of circumstances, will leave important needs unfulfilled and important tasks undone. We cannot provide every needed resource for every needy citizen. As we determine the necessary priorities, however, we must learn to say "no" and to live with the consequences. The "rebuttable presumption" approach can minimize the adverse impact that stratified scarcity has upon the poor. At the same time, it ensures that health care providers are not held unfairly hable for social inequities they did not create.

189. This argument was suggested to me by Rand Rosenblatt, J.D.

190. This is not a returu to the "charitable immunity" rules that have been roundly discarded by the courts. See, e.g., Bing v. Thunig, 2 N.Y.2d 656, 143 N.E.2d 3 (1957). Under that rule, charitable institutions were presumptively held less liable than for-profit institutions-that is, they were not presumed to be equally liable as under the "rebuttable presumption" approach. Rather, the resources-defense here is more akin to the locality rule, in which we acknowledge that physicians are not obligated to provide interventions that are not reasonably available. 


$$
\text { . }
$$




\section{California Law Review}

\begin{tabular}{lll}
\hline VoL. 75 & OCTOBER 1987 & No. 5 \\
\hline
\end{tabular}

Copyright (C) 1987 by California Law Review, Inc.

\section{BOARD OF EDITORS}

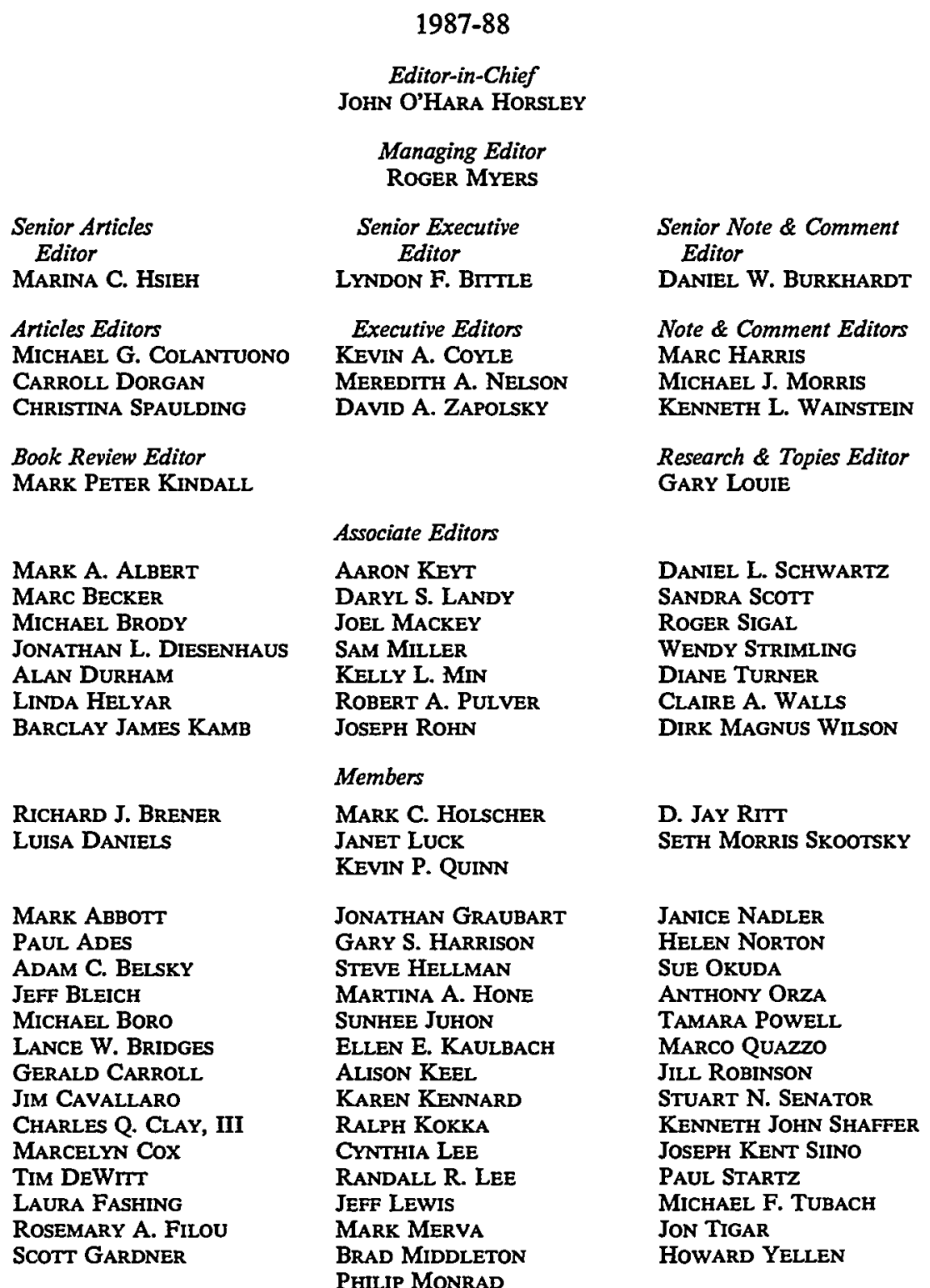


